\title{
Effects of Support and Rh Additive on Co-Based Catalysts in the Ethanol Steam Reforming Reaction
}

\author{
Zs. Ferencz, ${ }^{\dagger}$ A. Erdőhelyi, ${ }^{\dagger}$ K. Baán, ${ }^{\dagger}$ A. Oszkó, ${ }^{\dagger}$ L. Óvári, ${ }^{\ddagger}$ Z. Kónya, ${ }^{\ddagger}{ }^{\S}$ C. Papp, ${ }^{\|}$H.-P. Steinrück, $"$ \\ and J. Kiss $*, \dagger,+$
}

${ }^{\dagger}$ Department of Physical Chemistry and Materials Science, University of Szeged, Aradi vértanúk tere 1., Szeged H-6720, Hungary

${ }^{\ddagger}$ MTA-SZTE Reaction Kinetics and Surface Chemistry Research Group, Rerrich Béla tér 1., Szeged H-6720, Hungary

${ }^{\S}$ Department of Applied and Environmental Chemistry, University of Szeged, Rerrich Béla tér 1., Szeged H-6720, Hungary

"Physikaliche Chemie II, University of Erlangen-Nürnberg, Egerlandstr. 3, 91058 Erlangen, Germany

\section{Supporting Information}

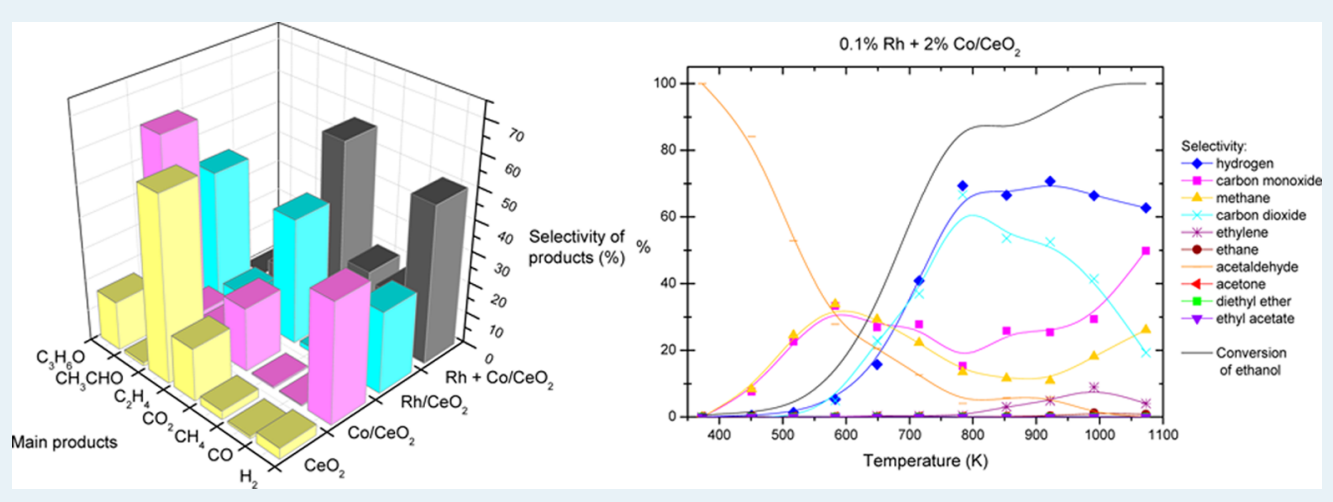

ABSTRACT: The effect of the nature of the support and the promotion achieved by a Rh additive on Co-based catalysts in the ethanol steam reforming reaction were studied. The catalysts with $2 \%$ Co loading were characterized by temperatureprogrammed reduction (TPR) and X-ray photoelectron spectroscopy (XPS). In situ diffuse reflectance Fourier-transform infrared spectroscopy (DRIFTS) identified the surface intermediates formed during the reaction, whereas gas phase products were detected by gas chromatography (GC). Upon heating in hydrogen to $773 \mathrm{~K}$, cobalt could not be reduced to Co on alumina, but on silica the reduction was almost complete. On ceria, half of the Co could be reduced to the metallic state. By the presence of a small amount $(0.1 \%)$ of $\mathrm{Rh}$ promoter, the reduction of both cobalt and ceria was greatly enhanced. For Co on the acidic $\mathrm{Al}_{2} \mathrm{O}_{3}$ support, the dehydration mechanism was dominant, although on the basic $\mathrm{CeO}_{2}$ support, a significant amount of hydrogen was also formed. Addition of a small amount of $\mathrm{Rh}$ as promoter to the $\mathrm{Co} / \mathrm{CeO}_{2}$ catalyst resulted in a significant further increase in the hydrogen selectivity.

KEYWORDS: ethanol steam reforming, hydrogen production, cobalt-ceria catalyst, rhodium promoter, ethoxide, DRIFTS, XPS

\section{INTRODUCTION}

Great efforts are currently undertaken to produce hydrogen, for example, for fuel cell applications and for ammonia synthesis by heterogeneously catalyzed processes from renewable sources. This demand inspired studies of the dehydrogenation of oxygenated hydrocarbons. ${ }^{1-6}$ In particular, the light alcohol ethanol is an important candidate as a chemical hydrogen carrier. Noble metals, especially $\mathrm{Rh}$, proved to be excellent catalysts for the dehydrogenation reaction, ${ }^{7,8}$ but their price is prohibitively high. As an alternative, the less expensive transition metal Co is considered a promising catalyst for the steam reforming of ethanol (SRE). ${ }^{9-11}$

During SRE, acidic supports like $\mathrm{Al}_{2} \mathrm{O}_{3}$ favor dehydration and thereby increase the tendency for coke formation due to the polymerization of ethylene. ${ }^{12-14}$ However, on ceria $\left(\mathrm{CeO}_{2}\right)$, which is considered to be a basic support, dehydration is limited and its redox properties hinder coke formation. ${ }^{6,15}$ Additionally, ceria promotes the water gas shift (WGS) reaction. ${ }^{3}$ Cobalt as catalyst achieves high ethanol conversion and selectivities of over $90 \%$ for $\mathrm{H}_{2}$ and $\mathrm{CO}_{2}$ on $\mathrm{CeO}_{2}$ and also on other supports. ${ }^{16,17}$ Supported Co catalysts break the $\mathrm{C}-\mathrm{C}$ bond in adsorbed ethanol. ${ }^{18}$ It was found that addition of a $\mathrm{CeO}_{2}$ promoter to an unsupported $\mathrm{Co}$ powder catalyst stabilizes the more active Co hcp structure and hinders sintering during SRE. ${ }^{19}$ Cobalt-based catalysts are also widely used in the reaction of $\mathrm{CO}$ and $\mathrm{H}_{2}$ to form linear aliphatic hydrocarbons with a broad molecular weight distribution. ${ }^{20,21}$ Bartholomew and co-workers pointed out that Fischer-

Received: January 14, 2014

Revised: $\quad$ March 5, 2014 
Tropsch (FT) synthesis under certain reaction conditions could be structure sensitive. ${ }^{22}$ The activity and selectivity appeared to be more closely related to the chemical nature of the support than to the Co dispersion. ${ }^{23,24}$ Also, for the reactions of ethanol, similar phenomena should be considered.

Another important physical chemical property of the oxide support is its reducibility. Redox supports such as ceria improve catalyst stability due to their high oxygen storage capacity (OSC) and oxygen mobility. The oxygen exchange capacity of cerium oxide is associated with its ability to reversibly change oxidation states between $\mathrm{Ce}^{4+}$ and $\mathrm{Ce}^{3+} \cdot{ }^{25-27}$ The easily accessible oxygen can react with carbon species as soon as it forms, and this process keeps the metal surface free of carbon, thus inhibiting deactivation., $9,28,29$

Naturally, the surface properties of the metal and the oxide support and also the metal/oxide interface determine the formation and stability of the intermediates present in the ethanol transformation process. It is generally accepted that the primary step in alcohol activation is the formation of alkoxide. ${ }^{30}$ Depending on the particular metal, dehydrogenation and $\mathrm{C}-\mathrm{C}$ bond scission lead to the formation of alkoxide, oxametallacycle, aldehyde, acyl, and coke on the surface and mostly $\mathrm{H}_{2}$, $\mathrm{CH}_{4}, \mathrm{CO}$, and aldehyde in the gas phase. ${ }^{30-40}$ Recent studies suggested that $\mathrm{Co}^{2+}$ sites are the active centers in SRE, and $\mathrm{Co}^{0}$ sites are responsible for coke formation; ${ }^{39,41}$ however, other authors considered metallic cobalt to play the key role in SRE. ${ }^{42}$ High-pressure X-ray photoelectron spectroscopic studies (HPXPS) demonstrated that during the reaction of ethanol with the $\mathrm{Co} / \mathrm{CeO}_{2}(111)$ model catalyst, the amount of $\mathrm{Co}^{2+}$ decreased drastically with increasing temperature, and at $600 \mathrm{~K}$ the majority of Co was metallic; this process was accompanied by a severe reduction of the ceria. ${ }^{43}$

Recently, the effect of adding small quantities of noble metals was investigated on alumina and ceria-zirconia type supports. ${ }^{44-46}$ The results showed that the promoting effect of noble metals included a marked decrease in the reduction temperatures of $\mathrm{Co}_{3} \mathrm{O}_{4}$ and cobalt oxide surface species due to the hydrogen spillover effect.

In the present work, we aim at finding correlations between the surface properties of supported Co catalysts (such as acidbase character or reducibility with and without a small amount of $\mathrm{Rh}$ loading) and their catalytic activity in ethanol steam reforming. The different Co-containing catalysts are characterized by X-ray photoelectron spectroscopy (XPS), X-ray diffraction (XRD), diffuse reflectance infrared Fourier transform spectroscopy (DRIFTS), and temperature-programmed reduction (spectroscopy) (TPR).

\section{EXPERIMENTAL SECTION}

The catalysts were prepared by impregnating the supports $\left(\mathrm{Al}_{2} \mathrm{O}_{3}\right.$ (Degussa P110 C1, $100 \mathrm{~m}^{2} / \mathrm{g}$ ), $\mathrm{CeO}_{2}$ (Alfa Aesar, $43 \mathrm{~m}^{2} / \mathrm{g}$ ), and $\mathrm{SiO}_{2}$ (Cab-O-Sil M5, $\left.200 \mathrm{~m}^{2} / \mathrm{g}\right)$ ) with the aqueous solution of $\mathrm{Co}\left(\mathrm{NO}_{3}\right)_{2}$ to yield a nominal metal content of 2 wt \%, if not mentioned otherwise. The impregnated powders were dried at $383 \mathrm{~K}$, calcined at $973 \mathrm{~K}$, and pressed to pellets. The $\mathrm{Rh}-\mathrm{Co}$ bimetallic samples were prepared by sequential impregnation (impregnation with Co and calcination first, then the same procedure after impregnation with $\mathrm{Rh}$ ). Before the measurements, fragments of catalyst pellets were oxidized at $673 \mathrm{~K}$ in flowing $\mathrm{O}_{2}$ for $20 \mathrm{~min}$ and reduced at $673 \mathrm{~K}$ in flowing $\mathrm{H}_{2}$ for $60 \mathrm{~min}$ in the catalytic reactor.

Catalytic reactions were carried out in a fixed-bed continuous-flow reactor $(200 \mathrm{~mm}$ long with $8 \mathrm{~mm}$ i.d.), which was heated externally. The dead volume of the reactor was filled with quartz beads. The operating temperature was controlled by a thermocouple placed inside the oven close to the reactor wall, to ensure precise temperature measurement. For catalytic studies, small fragments (about $1 \mathrm{~mm}$ ) of slightly compressed pellets were used. Typically, the reactor filling contained $50 \mathrm{mg}$ of catalyst. In the reacting gas mixture, the ethanol/ water molar ratio was $1: 3$, if not denoted otherwise. The ethanolwater mixture was introduced into an evaporator with the help of an HPLC pump (Younglin; flow rate: $0.007 \mathrm{~mL}$ liquid/min); the evaporator was flushed with Ar flow $(60 \mathrm{~mL} / \mathrm{min})$. Argon was used as a carrier gas $(60 \mathrm{~mL} / \mathrm{min})$. The reacting gas mixture-containing $\mathrm{Ar}$ flow entered the reactor through an externally heated tube in order to avoid condensation. The space velocity was $60000 \mathrm{~h}^{-1}$.

The analysis of the products and reactants was performed with an Agilent $6890 \mathrm{~N}$ gas chromatograph using HP-PLOT Q column. The gases were detected simultaneously by thermal conductivity (TC) and flame ionization (FI) detectors. To increase the sensitivity of $\mathrm{CO}$ and $\mathrm{CO}_{2}$ detection, a methanizer was applied before the detectors.

The rate of ethanol decomposition was defined in terms of conversion, $X_{\text {ehanol }}$, whereas the product selectivities were denoted as $S_{\text {product }}$ The selectivities, $S_{i j}$ toward carbon monoxide, carbon dioxide, methane, ethane, ethylene, acetone, diethyl ether, ethyl acetate, and acetaldehyde were calculated via the carbon balance, defined as the ratio of the product moles to the consumed moles of ethanol, accounting for stoichiometry. The hydrogen selectivity, $S_{\mathrm{H}_{2}}$, was calculated by the hydrogen balance, defined as the molar fraction of hydrogen produced to the total hydrogen in the products:

$$
S_{i}=\frac{x_{i} n_{i}}{\sum_{j} x_{j} n_{j}} S_{\mathrm{H}_{2}}=\frac{2 x_{\mathrm{H}_{2}}}{\sum_{j} x_{j} n_{j}}
$$

where $x_{i}$ and $x_{\mathrm{H} 2}$ denote the mole fraction of product $(i)$ and $\mathrm{H}_{2}$, respectively; $n_{j}$ in $S_{i}$ is the number of carbon atoms in each molecule of the carbon-containing product $(j)$, whereas $n_{j}$ in $S_{\mathrm{H}_{2}}$ is the number of hydrogen atoms in each molecule of the hydrogen-containing product $(j)$. The summation goes for all products.

The amount and the reactivity of surface carbon formed in the catalytic reactions were determined by temperature-programmed hydrogenation. After performing the reactions of ethanol-water mixtures at $823 \mathrm{~K}$ for $120 \mathrm{~min}$, the reactor was flushed with $\mathrm{Ar}$ at the reaction temperature; then the sample was cooled to $373 \mathrm{~K}$, the $\mathrm{Ar}$ flow was changed to $\mathrm{H}_{2}$, and the sample was heated up to $1173 \mathrm{~K}$ with a $10 \mathrm{~K} / \mathrm{min}$ heating rate. The formed hydrocarbons were determined and quantified by gas chromatography.

For XPS studies, the powder samples were pressed into pellets with ca. $1 \mathrm{~cm}$ diameter and a few tenth of mm thickness, which were placed into the load lock of the spectrometer. Sample treatments were carried out in a high-pressure cell (catalytic chamber) connected to the analysis chamber via a gate valve. They were pretreated in the same way as described above. After the pretreatment, they were cooled to room temperature in flowing nitrogen. Then, the high-pressure cell was evacuated, and the sample was transferred to the analysis chamber in high vacuum (i.e., without contact to air), where the XP spectra were recorded. As the next step, the sample was moved back into the catalytic chamber, where it was treated with the reacting gas mixture at the reaction temperature with the same experimental conditions as used for the catalytic reaction. XP spectra were taken with a SPECS instrument equipped with a PHOIBOS $150 \mathrm{MCD} 9$ hemispherical electron energy analyzer, using $\mathrm{Mg} \mathrm{K} \alpha$ radiation $(\mathrm{h} \nu=1253.6 \mathrm{eV})$. The X-ray gun was operated at $210 \mathrm{~W}(14 \mathrm{kV}, 15 \mathrm{~mA})$. The analyzer was operated in the FAT mode, with the pass energy set to $20 \mathrm{eV}$. The takeoff angle of electrons was $20^{\circ}$ with respect to surface normal. Typically five scans were summed to get a single spectrum. For data acquisition and evaluation, both manufacturer's (SpecsLab2) and commercial (CasaXPS, Origin) software were used. A charging of several electron volts was experienced for all samples. The binding energy scale was corrected by fixing the Ce $3 \mathrm{~d} \mathrm{u}$ "' peak (see below) to $916.8 \mathrm{eV}$, the $\mathrm{Al} 2 \mathrm{p}$ peak to $74.7 \mathrm{eV}$, and the $\mathrm{Si} 2 \mathrm{p}$ peak to $103.4 \mathrm{eV}$, when using the given supports.

The BET surface and pore volume measurements of the catalysts were carried out by a Quantachrome NOVA 3000e instrument using 
$\mathrm{N}_{2}$ adsorption at liquid nitrogen temperature (Table 1). Apparently, the calcination and the presence of Co only slightly modified the

Table 1. Surface area $\left(S_{\mathrm{A}}\right)$, Pore Volume, and Pore Radius of Bare Supports and Co- and Rh-Loaded Catalysts

\begin{tabular}{lccc}
\multicolumn{1}{c}{ catalyst $^{a}$} & $\begin{array}{c}S_{\mathrm{A}} \\
\left(\mathrm{m}^{2} / \mathrm{g}\right)\end{array}$ & $\begin{array}{c}\text { total pore volume } \\
\left(\mathrm{cm}^{3} / \mathrm{g}\right) \text { at } \\
p / p_{0}=0.99\end{array}$ & $\begin{array}{c}\text { average pore } \\
\text { radius }(\mathrm{nm})\end{array}$ \\
$\mathrm{Al}_{2} \mathrm{O}_{3}$ & 110 & 0.910 & 16.4 \\
$2 \% \mathrm{Co} / \mathrm{Al}_{2} \mathrm{O}_{3}$ & 90.8 & 0.715 & 15.7 \\
$\mathrm{SiO}_{2}$ & 175 & 1.620 & 17.5 \\
$2 \% \mathrm{Co} / \mathrm{SiO}_{2}$ & 168 & 1.430 & 17.0 \\
$\mathrm{CeO}_{2}$ & 21.5 & 0.156 & 14.5 \\
$2 \% \mathrm{Co} / \mathrm{CeO}_{2}$ & 7.4 & 0.045 & 12.3 \\
$10 \% \mathrm{Co} / \mathrm{CeO}_{2}$ & 6.8 & 0.041 & 11.7 \\
$0.1 \% \mathrm{Rh} / \mathrm{CeO}_{2}$ & 19.8 & 0.148 & 14.2 \\
$0.1 \% \mathrm{Rh}+2 \% \mathrm{Co} / \mathrm{CeO}_{2}$ & 7.6 & 0.050 & 13.3 \\
${ }^{\mathrm{T}}$ The samples were calcined at $973 \mathrm{~K}$. & & \\
& & &
\end{tabular}

surface area of $\mathrm{Al}_{2} \mathrm{O}_{3}$ - and $\mathrm{SiO}_{2}$-supported catalysts. On the other hand, the calcination led to a significant loss of area for $\mathrm{CeO}_{2}$, which was further lowered due to $\mathrm{Co}$ loading. The porosity of $\mathrm{CeO}_{2}$ supported catalysts was very poor compared to alumina and silica supports, in accordance with previous studies. ${ }^{10}$ The temperatureprogrammed reduction (TPR) was carried out in a BELCAT-A apparatus using a reactor (quartz tube with $9 \mathrm{~mm}$ outer diameter) that was externally heated. Before the measurements, the catalyst samples were treated in oxygen at $673 \mathrm{~K}$ for $30 \mathrm{~min}$. Thereafter, the sample was cooled in flowing Ar to room temperature and equilibrated for $15 \mathrm{~min}$. The oxidized sample was flushed with $\mathrm{Ar}$ containing $10 \% \mathrm{H}_{2}$, the reactor was heated linearly at a rate of $20 \mathrm{~K} / \mathrm{min}$ up to $1373 \mathrm{~K}$, and the $\mathrm{H}_{2}$ consumption was detected by a thermal conductivity detector (TCD).

In situ DRIFTS (diffuse reflectance infrared Fourier transform spectroscopy) was used to examine the adsorbed species on the catalysts during the catalytic reactions. The system consists of an FTIR spectrometer (Bio-Rad 135) equipped with a diffuse reflectance attachment (Thermo Scientific) with $\mathrm{BaF}_{2}$ windows. Following the aforementioned pretreatment steps, the sample was cooled to room temperature under helium flow, and a background file of the pretreated sample was registered.

At room temperature, the ethanol steam reforming feed with a water-to-ethanol molar ratio of 3:1 was introduced to the DRIFTS cell. The feed stream was obtained by flowing helium through an evaporator connected to an infusion pump (Econoflow 84 with the flow rate $0.3 \mathrm{~mL}$ liquid/h). The tubes were externally heated to avoid condensation. The catalyst was heated under the reaction feed linearly from room temperature to $873 \mathrm{~K}$ with a heating rate of $20 \mathrm{~K} / \mathrm{min}$, and IR spectra were measured in $50 \mathrm{~K}$ intervals. All spectra were recorded between 4000 and $900 \mathrm{~cm}^{-1}$ at a resolution of $4 \mathrm{~cm}^{-1}$. Typically 32 scans were registered; the spectrum of the pretreated catalysts was used as a background. The whole optical path-with the exception of the IR cell-was purged with $\mathrm{CO}_{2}$ - and $\mathrm{H}_{2} \mathrm{O}$-free air generated by a Balston purge gas generator. Due to the short optical path within the DRIFTS cell, the contribution of the reactant gases was negligibly small, and from gas phase products only the most intense features were observable.

The XRD study was carried out on a Rigaku Miniflex II powder Xray diffractometer equipped with a $\mathrm{Cu} \mathrm{K} \alpha$ radiation source $(\lambda=$ $0.15418 \mathrm{~nm}$ ) by applying a scanning rate of $4 \mathrm{deg} / \mathrm{min}$ in the $2 \theta$ range of $3-80^{\circ}$.

\section{RESULTS AND DISCUSSION}

3.1. Temperature-Programmed Reduction. TPR profiles were obtained to investigate the oxide phases present on the catalysts and to evaluate their thermal stability. The reducibility of supported Co catalysts depends on the nature of oxide support, the calcination temperature, and the amount of metal loading. Figure 1 shows the reduction profiles of the

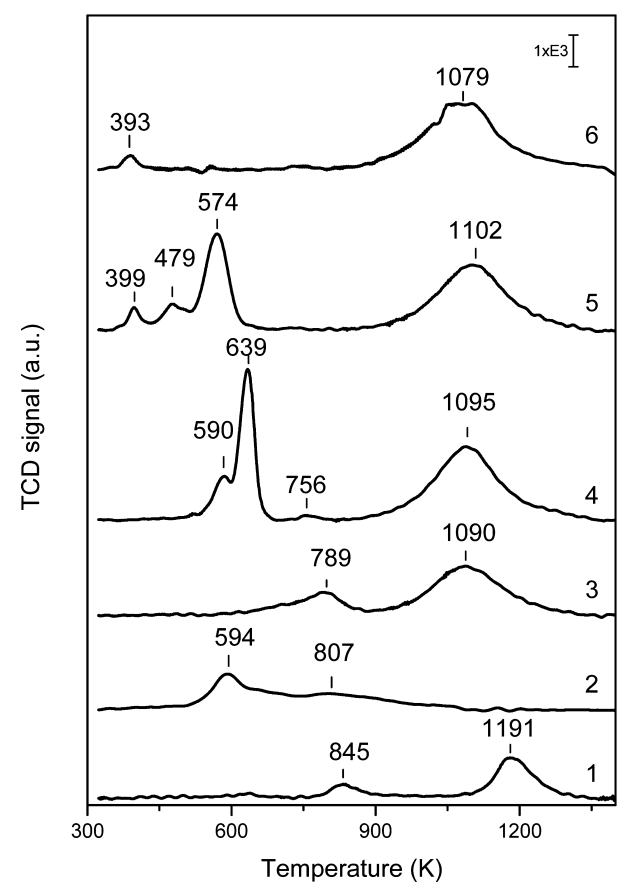

Figure 1. TPR profile of $2 \% \mathrm{Co} / \mathrm{Al}_{2} \mathrm{O}_{3}(1), 2 \% \mathrm{Co} / \mathrm{SiO}_{2}(2), \mathrm{CeO}_{2}$ (3), $2 \% \mathrm{Co} / \mathrm{CeO}_{2}$ (4), $0.1 \% \mathrm{Rh}+2 \% \mathrm{Co} / \mathrm{CeO}_{2}(5)$, and $0.1 \% \mathrm{Rh} /$ $\mathrm{CeO}_{2}$ (6). The oxidized sample was flushed with $\mathrm{Ar}$ containing $10 \%$ $\mathrm{H}_{2}$, and the reactor was heated linearly at a rate of $20 \mathrm{~K} / \mathrm{min}$ up to $1373 \mathrm{~K}$.

catalysts containing $2 \%$ Co using different supports. In the case of $\mathrm{CeO}_{2}$, for comparison, the TPR curve of the pure oxide and those of the $0.1 \% \mathrm{Rh}+2 \% \mathrm{Co} / \mathrm{CeO}_{2}$ and $0.1 \% \mathrm{Rh} / \mathrm{CeO}_{2}$ catalysts are also displayed in Figure 1.

The TPR profile of $\mathrm{Co} / \mathrm{Al}_{2} \mathrm{O}_{3}$ at $2 \%$ Co content (spectrum 1) exhibits a peak at $845 \mathrm{~K}$ and a high-temperature reduction peak at $1191 \mathrm{~K}$. For higher metal contents or lower calcination temperatures, the low-temperature reduction peak appears at somewhat lower temperature $(\sim 800 \mathrm{~K})$. Some authors suggest that this peak corresponds to the reduction of large crystalline $\mathrm{Co}_{3} \mathrm{O}_{4}$ particles to $\mathrm{Co}^{0}$ via $\mathrm{CoO}$ formation, ${ }^{47}$ although others ascribe it only to the reduction of $\mathrm{Co}_{3} \mathrm{O}_{4}$ to $\mathrm{CoO} .{ }^{48}$ The higher temperature peak is consistently assigned to the reduction of $\mathrm{Co}^{3+}$ and $\mathrm{Co}^{2+}$ species, which are highly dispersed on the surface and strongly interact with alumina, ${ }^{47,48}$ forming aluminate compounds during the calcinations process. The latter process is further confirmed by our XRD measurements.

For $\mathrm{Co} / \mathrm{SiO}_{2}$ with Co loadings of $2 \%$ (spectrum 2) (also for loadings of $10 \%$, data not shown), an intense reduction peak was observed between 500 and $650 \mathrm{~K}$, with the peak maximum at $600 \pm 20 \mathrm{~K}$. In addition, a small, broad peak was detected around $800 \pm 100 \mathrm{~K}$. The $\mathrm{H}_{2}-\mathrm{TPR}$ profiles for a $2 \% \mathrm{Co} / \mathrm{SiO}_{2}$ sample in Figure 1, with the rate maximum of the low temperature peak at $594 \mathrm{~K}$, agrees well with literature data. ${ }^{49}$ This $\mathrm{H}_{2}$ consumption is assigned to the reduction of $\mathrm{Co}_{3} \mathrm{O}_{4}$ to $\mathrm{Co}^{0.50,51}$ The weak high-temperature peak at $807 \mathrm{~K}$ has been ascribed to surface cobalt hydroxy silicates, which develop upon reaction of surface silanol groups of the silica support, and is indicative of a limited metal-support interaction. ${ }^{49,52}$ For a Co loading of $10 \%$, the peak assigned to reduction of oxide to 


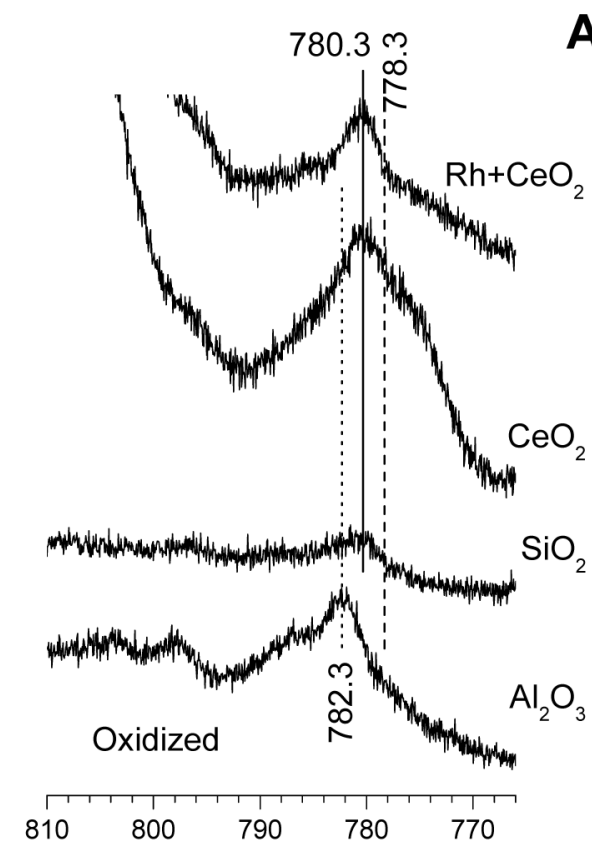

A

Binding energy $[\mathrm{eV}]$

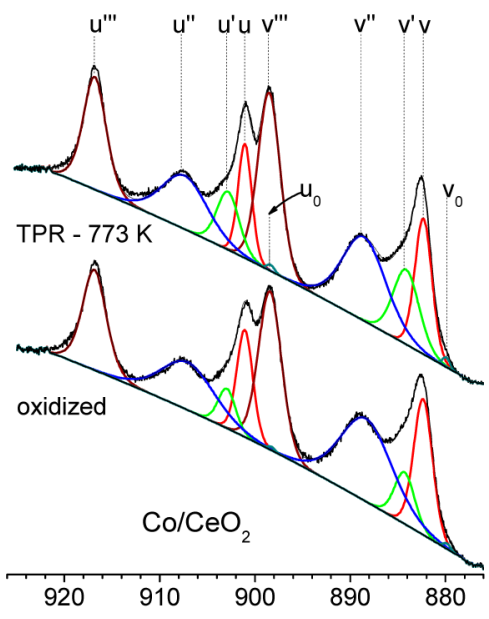

B
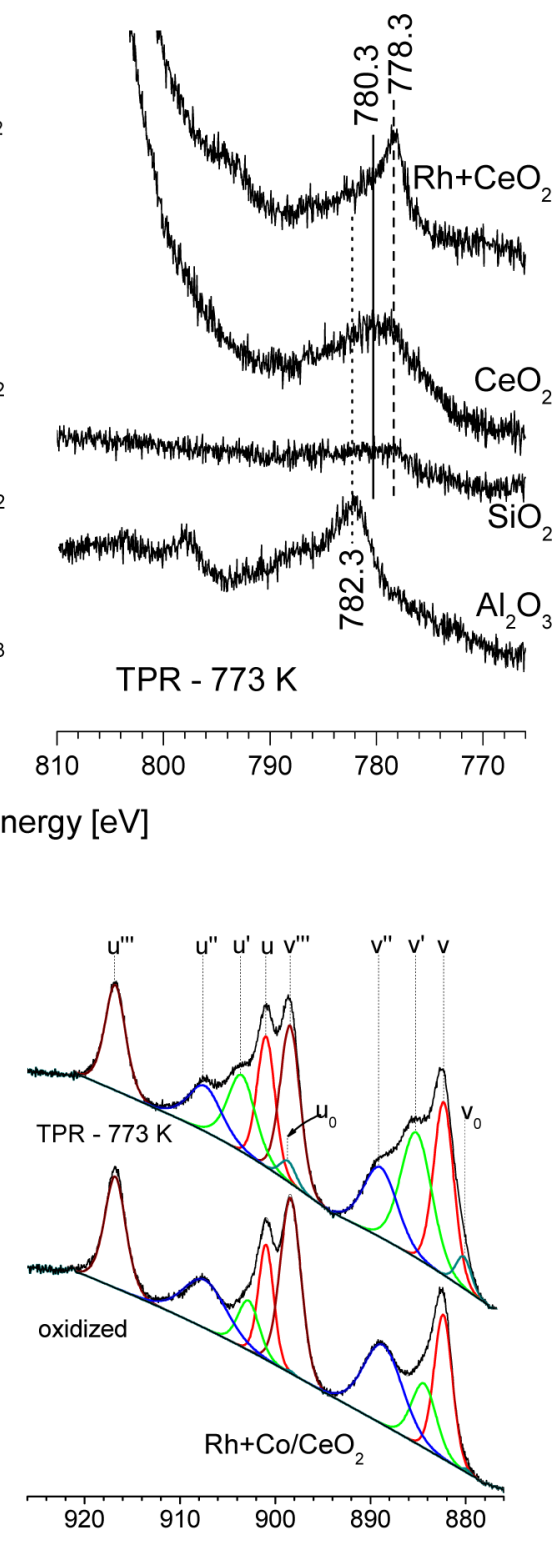

Binding energy $[\mathrm{eV}]$

Figure 2. (A) Co $2 \mathrm{p} \mathrm{XP}$ spectra on different supports after oxidation at $673 \mathrm{~K}$ for $30 \mathrm{~min}$ (left) and after linear heating $(20 \mathrm{~K} / \mathrm{min})$ in $\mathrm{H}_{2}$ to $773 \mathrm{~K}$ (right). (B) Ce $3 \mathrm{~d}$ XP spectra taken on a $2 \% \mathrm{Co} / \mathrm{CeO}_{2}$ catalyst (left) and $0.1 \% \mathrm{Rh}+2 \% \mathrm{Co} / \mathrm{CeO}_{2}$ catalyst (right) after oxidation at $673 \mathrm{~K}$ and after reduction with the TPR run up to $773 \mathrm{~K}$.

metallic Co increased significantly and shifted to $643 \mathrm{~K}$ (not shown).

Before we move on to the loaded support, we first discuss the data for the pure $\mathrm{CeO}_{2}$ support (spectrum 3). They display an asymmetric low-temperature feature with a rate maximum at $789 \mathrm{~K}$ (note that its intensity gradually decreased as TPR runs were repeated, indicating a reduction in the surface region). In addition, a pronounced high-temperature peak was detected at $1090 \mathrm{~K}$, attributed to the bulk reduction of the ceria support. ${ }^{53}$

Upon adding $2 \% \mathrm{Co}$ on the $\mathrm{CeO}_{2}$ (spectrum 4), the hightemperature feature shows a slight increase, and an additional well-resolved doublet appeared, with peak maxima at 590 and $639 \mathrm{~K}$. This characteristic reduction profile has been previously reported for $\mathrm{Co} / \mathrm{CeO}_{2}{ }^{10}$ and is consistent with a stepwise reduction scheme, first from $\mathrm{Co}_{3} \mathrm{O}_{4}$ to $\mathrm{CoO}$ and thereafter from $\mathrm{CoO}$ to metallic Co. Because XPS results on $2 \% \mathrm{Co} /$ $\mathrm{CeO}_{2}$ (see below) indicated that the reduction of $\mathrm{Co}$ is not complete up to $773 \mathrm{~K}$, the slightly increased high temperature feature at $1095 \mathrm{~K}$ probably also contains a contribution from the reduction of Co. When the Co loading was increased to $10 \%$, the intensity of the low-temperature doublet increased and shifted to lower temperatures (563 and $626 \mathrm{~K}$, not shown), and the peak at around $756 \mathrm{~K}$ significantly intensified.

Adding a small amount of noble metal $(0.1 \% \mathrm{Rh})$ to $2 \% \mathrm{Co}-$ supported on $\mathrm{CeO}_{2}$ (spectrum 5) altered the TPR profile significantly. The doublet moved to lower temperatures (479 and $574 \mathrm{~K}$ ), with the shift being more pronounced for the lower temperature peak (i.e., for reduction of $\mathrm{Co}_{3} \mathrm{O}_{4}$ to $\mathrm{CoO}$ ). The peak observed at $756 \mathrm{~K}$ without the noble metal promoter practically disappeared, and the high temperature peak (1102 
A

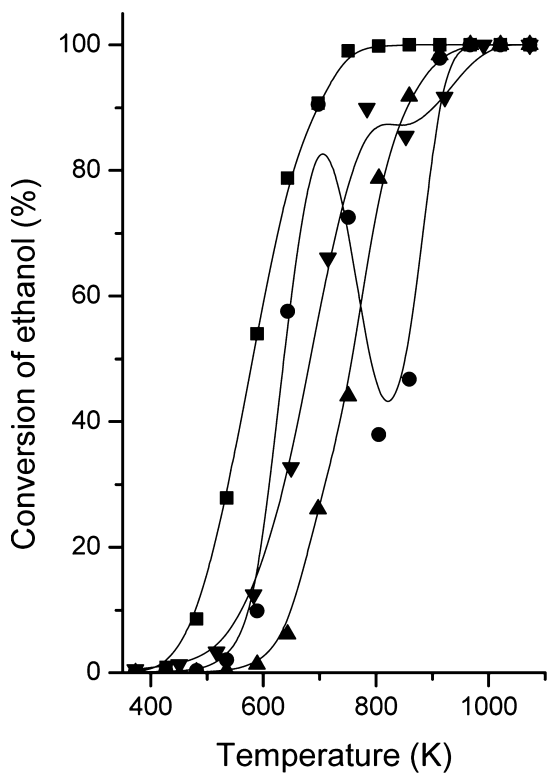

B

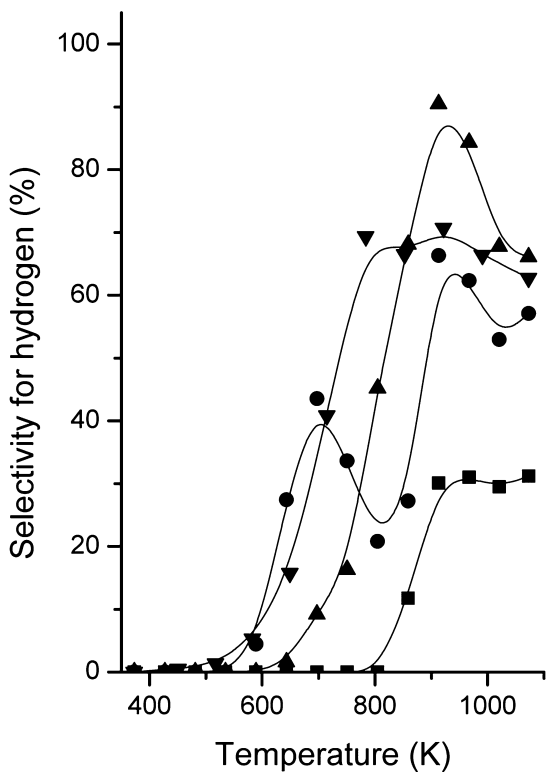

Figure 3. Conversion of ethanol (A) and selectivity of hydrogen (B) as a function of temperature on $2 \% \mathrm{Co} / \mathrm{Al}_{2} \mathrm{O}_{3}(\boldsymbol{\square}), 2 \% \mathrm{Co} / \mathrm{SiO} 2(\boldsymbol{\Delta}), 2 \% \mathrm{Co} /$ $\mathrm{CeO}_{2}(\bullet)$, and $0.1 \% \mathrm{Rh}+2 \% \mathrm{Co} / \mathrm{CeO}_{2}(\boldsymbol{\nabla})$ catalysts.

K) remained more or less unchanged. In addition, a new peak appeared at $399 \mathrm{~K}$, corresponding to the reduction of $\mathrm{Rh}$ particles. ${ }^{53}$ From these observations, we conclude that small amounts of Rh facilitate the reduction of cobalt oxides. Similar noble metal effects were observed for alumina-supported cobalt Fischer-Tropsch catalysts. ${ }^{46,54}$ Presumably, this effect can be attributed to the spillover of hydrogen from $\mathrm{Rh}$ to $\mathrm{CoO}_{x}$. Similar promoter effects were also found to play an important role on alumina-supported $\mathrm{Co} / \mathrm{Re}, \mathrm{Co} / \mathrm{Pt}$, and $\mathrm{Co} / \mathrm{Ru}$ catalysts $^{46}$ and on other bimetallic cobalt based systems. ${ }^{6,13,55}$ The TPR profile of $0.1 \% \mathrm{Rh} / \mathrm{CeO}_{2}$ without Co content is also displayed in Figure 1 (spectrum 6). The peak for reduction of $\mathrm{Rh}$ particles appeared at $393 \mathrm{~K}$.

3.2. X-ray Photoelectron Spectroscopy. Figure 2A shows the X-ray photoelectron spectra in the Co $2 \mathrm{p}$ region after oxidation (at $673 \mathrm{~K}$ for $30 \mathrm{~min}$ ) and after hydrogen reduction at $773 \mathrm{~K}$ (after TPR experiments) on different supports. In literature, for metallic cobalt $\left(\mathrm{Co}^{\circ}\right)$, an asymmetric Co $2 \mathrm{p}_{3 / 2}$ peak is observed at $778.0-778.5 \mathrm{eV}$, and $\mathrm{Co}^{2+}$ is characterized by a Co $2 \mathrm{p}_{3 / 2}$ peak at $780-781 \mathrm{eV}$, with a strong satellite at $786-787 \mathrm{eV}$. The signature of $\mathrm{Co}^{3+}$ is a Co $2 \mathrm{p}_{3 / 2}$ peak at $780-781 \mathrm{eV}$ with no satellite. ${ }^{29,39,56}$

On the alumina support, the Co $2 \mathrm{p}_{3 / 2}$ and $2 \mathrm{p}_{1 / 2}$ levels were observed at 782.3 and $798.2 \mathrm{eV}$, respectively, with both spinorbit split levels displaying satellites (left panel in Figure 2A). We attribute these spectra for $\mathrm{Co} / \mathrm{Al}_{2} \mathrm{O}_{3}$ to a $\mathrm{Co}$-aluminate spinel, which was obtained previously in the literature. ${ }^{57}$ When the sample was reduced up to $773 \mathrm{~K}$, the spectrum did not change significantly (right panel in Figure 2A). Thus, in accordance with the TPR measurements, no metallic cobalt was detected. When $10 \%$ Co was applied, the peak positions remained (not shown), indicating that practically all Co is incorporated in the spinel structure in our case. The main conclusion of our TPR and XPS measurements, therefore, is that Co remained oxidized below $\sim 800 \mathrm{~K}$ even in reducing atmosphere.

On the $\mathrm{SiO}_{2}$ support, the intensity of the Co peaks was much smaller than on alumina, which is attributed to the formation of larger $\mathrm{Co} / \mathrm{CoO}_{x}$ particles. Co appeared in the $\mathrm{Co}^{2+}$ state after calcination and oxidation, as deduced from the Co $2 \mathrm{p}_{3 / 2}$ level at $780.3 \mathrm{eV}$ (Figure 2A, left). When the surface was reduced up to $773 \mathrm{~K}$, in contrast to the alumina support case, the Co $2 \mathrm{p}_{3 / 2}$ peak moved to $778.3 \mathrm{eV}$ (Figure 2A, right), which is characteristic for the metallic state. ${ }^{11,29,39}$ As the peak was very weak, we cannot exclude that a fraction remained in a partially oxidized state, which may correspond to cobalt hydroxy silicate species.

The $2 \%$ Co-supported on ceria showed an intense Co $2 \mathrm{p}_{3 / 2}$ peak at $780.3 \mathrm{eV}$, with a shoulder at lower binding energies, after oxidation (Figure 2A, left). Taking into account the literature data mentioned above, we conclude that the sample contains mainly $\mathrm{Co}^{2+}$ plus some metallic contribution. When the sample was reduced up to $773 \mathrm{~K}$ (Figure 2A, right), the Co $2 \mathrm{p}_{3 / 2}$ intensity decreased by more than a factor of 2 , and the metallic (778. Three $\mathrm{eV})$ and the $\mathrm{Co}^{2+}$ components $(780.3 \mathrm{eV})$ exhibited comparable intensities. This indicates that the Co oxide cannot be reduced completely at this temperature. The intensity change after the reduction treatment may reflect a slight encapsulation, sintering or diffusion into the bulk.

The Ce $3 \mathrm{~d}$ spectra of $\mathrm{Co} /$ ceria before and after reduction are shown in Figure 2B. Generally, the $\mathrm{Ce} 3 \mathrm{~d}$ region of $\mathrm{CeO}_{2}$ is rather complex, i.e. it is composed of three doublets, $\left(\mathrm{u}^{\prime \prime \prime}, \mathrm{v}^{\prime \prime \prime}\right)$, $\left(u^{\prime \prime}, v^{\prime \prime}\right)$ and $(u, v)$, corresponding to the emission from the spin-orbit split $3 \mathrm{~d}_{3 / 2}$ and $3 \mathrm{~d}_{5 / 2}$ core levels of $\mathrm{Ce}^{4+}$. The three doublets are assigned to different final states: $\mathrm{u}^{\prime \prime \prime}(916.8 \mathrm{eV})$ and $\mathrm{v}^{\prime \prime \prime}(898.4 \mathrm{eV})$ are due to a Ce $3 \mathrm{~d}^{9} 4 \mathrm{f}^{0} \mathrm{O} 2 \mathrm{p}^{6}$ final state, $\mathrm{u}^{\prime \prime}$ $(907.7 \mathrm{eV})$ and $\mathrm{v}^{\prime \prime}(889.0 \mathrm{eV})$ to a Ce $3 \mathrm{~d}^{9} 4 \mathrm{f}^{1} \mathrm{O} 2 \mathrm{p}^{5}$ final state, and $\mathrm{u}(900.9 \mathrm{eV})$ and $\mathrm{v}(882.5 \mathrm{eV})$ to a Ce $3 \mathrm{~d}^{9} 4 \mathrm{f}^{2} \mathrm{O} 2 \mathrm{p}^{4}$ final state. ${ }^{58-61}$ A minor reduction of $\mathrm{Ce}^{4+}$ to $\mathrm{Ce}^{3+}$ is best detectable as the small intensity increase of the $\mathrm{u}^{\prime}(903.9 \mathrm{eV})$ and $\mathrm{v}^{\prime}$ $(885.3 \mathrm{eV})$ peaks and also the weaker $\mathrm{u}_{0}(899.3 \mathrm{eV})$ and $\mathrm{v}_{0}$ $(880.2 \mathrm{eV})$ components, which are characteristic of $\mathrm{Ce}^{3+}$, after TPR of the $2 \% \mathrm{Co} / \mathrm{CeO}_{2}$ catalyst (Figure $2 \mathrm{~B}$ ).

Upon adding a small amount of $\mathrm{Rh}(0.1 \%)$ to the $2 \% \mathrm{Co} /$ $\mathrm{CeO}_{2}$ catalyst, pronounced changes of the Co $2 \mathrm{p}$ and $\mathrm{Ce} 3 \mathrm{~d}$ spectra were detected. After oxidation, a single Co $2 \mathrm{p}_{3 / 2}$ feature 
A

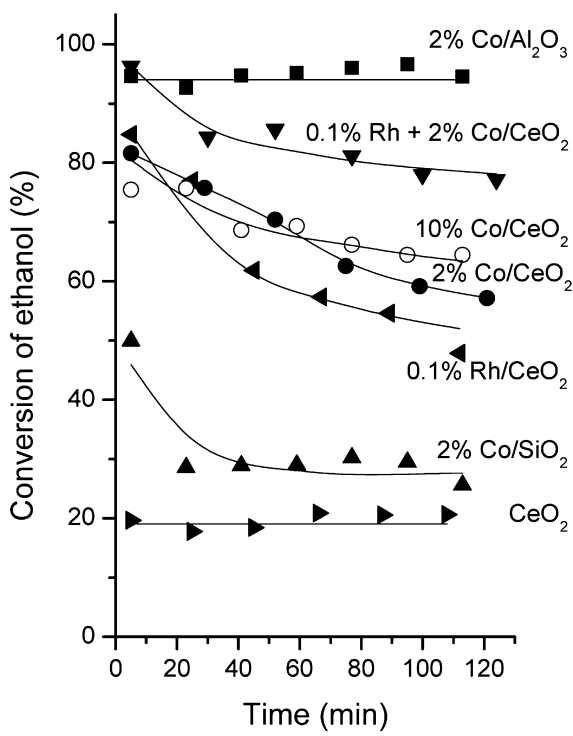

B

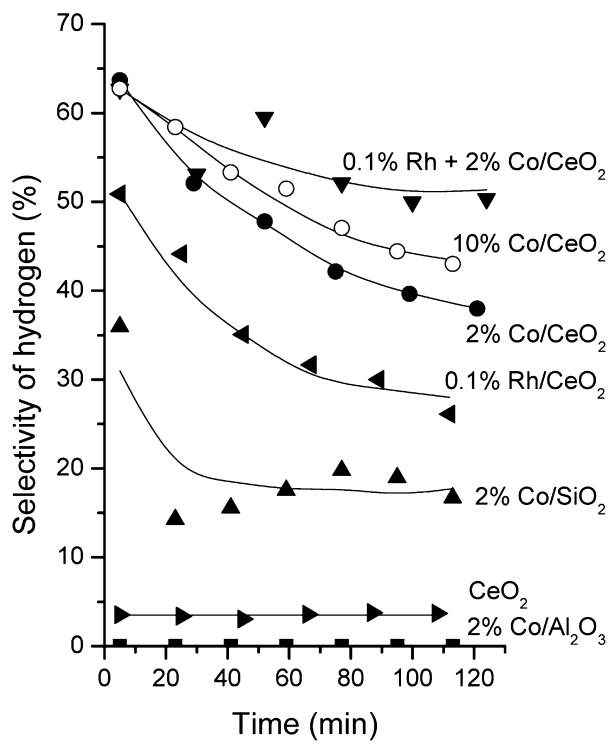

Figure 4. Conversion of ethanol (A) and selectivity of hydrogen (B) as a function of reaction time at $723 \mathrm{~K}$ on $2 \% \mathrm{Co} / \mathrm{Al}_{2} \mathrm{O}_{3}(\boldsymbol{\square}), 2 \% \mathrm{Co} / \mathrm{SiO} \mathrm{D}_{2}(\boldsymbol{\Delta})$, $2 \% \mathrm{Co} / \mathrm{CeO}_{2}(\bullet), 10 \% \mathrm{Co} / \mathrm{CeO}_{2}(\mathrm{O}), 0.1 \% \mathrm{Rh}+2 \% \mathrm{Co} / \mathrm{CeO}_{2}(\boldsymbol{\nabla}), 0.1 \% \mathrm{Rh} / \mathrm{CeO}_{2}$ (left-facing triangle), and $\mathrm{CeO}{ }_{2}$ (right-facing triangle) catalysts.

centered at $780.3 \mathrm{eV}$ appeared due to oxidized cobalt (Figure 2A, left). After TPR up to $773 \mathrm{~K}$ (TPR) (or alternatively at 673 $\mathrm{K}$ for $1 \mathrm{~h}$ ), the peak shifted to $778.3 \mathrm{eV}$ (Figure 2A, right), showing a nearly complete reduction of cobalt oxide to metallic cobalt. A similar drastic change was also found in the Ce $3 \mathrm{~d}$ spectra after reduction (Figure $2 \mathrm{~B}$ ). In particular, the significant intensity increases of the $\mathrm{v}^{\prime}(885.3 \mathrm{eV})$ and the $\mathrm{u}^{\prime}$ peaks (903.9 $\mathrm{eV})$ and also the $\mathrm{u}_{0}$ and $\mathrm{v}_{0}$ components, clearly indicate a strong reduction of $\mathrm{CeO}_{2}$. One of the main messages of this observation thus is that besides the reduction of cobalt on the $\mathrm{Rh}$-doped catalyst, also a considerable reduction of the ceria support occurred during TPR up to $773 \mathrm{~K}$. Presumably, the spillover of $\mathrm{H}$ from $\mathrm{Rh}$ to $\mathrm{CoO}_{x}$ and $\mathrm{CeO}_{2}$ plays an important role.

3.3. Steam Reforming of Ethanol over Co-Based Catalysts Using Different Supports. In the catalytic test reaction of ethanol-water steam reforming (1:3 ratio), the conversion of ethanol, the hydrogen selectivity, and the product distribution were studied on cobalt catalysts under the same conditions using different supports and the promoter $\mathrm{Rh}$.

Figure 3A shows the conversion of ethanol during heating (3 $\mathrm{K} / \mathrm{min}$ ) from 373 to $1073 \mathrm{~K}$. The $2 \% \mathrm{Co} / \mathrm{Al}_{2} \mathrm{O}_{3}$ catalyst displays the highest activity, with the reaction starting around $400 \mathrm{~K}$, and almost $100 \%$ conversion was reached at $700 \mathrm{~K}$. The $2 \% \mathrm{Co} / \mathrm{CeO}_{2}$ catalyst and $0.1 \% \mathrm{Rh}+2 \% \mathrm{Co} / \mathrm{CeO}_{2}$ catalyst were also very active, with the reaction starting at $\sim 500 \mathrm{~K}$. For the former, the increase to full conversion was not monotonous, but after a maximum at $\sim 700 \mathrm{~K}$, there was an intermediate minimum around $800 \mathrm{~K}$. This behavior is assigned either to ethanol desorption through recombinative pathways involving ethoxide or acetaldehyde or to desorption of molecularly adsorbed ethanol, which is present on the $2 \%$ $\mathrm{Co} / \mathrm{CeO}_{2}$ surface up to high temperatures (see DRIFT spectra, Figure $8 \mathrm{~A}$ ). On the $2 \% \mathrm{Co} / \mathrm{SiO}_{2}$ catalyst, the reaction started around $600 \mathrm{~K}$.

The hydrogen selectivity data, shown in Figure $3 \mathrm{~B}$ as a function of temperature, showed a value of $70 \%$ for the Rhpromoted $\mathrm{Co} / \mathrm{CeO}_{2}$ at $\sim 700 \mathrm{~K}$; on $\mathrm{Co} / \mathrm{SiO}_{2}$, hydrogen selectivity reached $90 \%$, with an onset at $\sim 650 \mathrm{~K}$. On alumina-supported $\mathrm{Co}$, hydrogen appeared only above $800 \mathrm{~K}$, and the maximum of hydrogen selectivity was only $~ 30 \%$.

We next address the product distribution (see Supporting Information). On $2 \% \mathrm{Co} / \mathrm{Al}_{2} \mathrm{O}_{3}$ at low temperature (i.e., up to $500 \mathrm{~K})$, when the conversion was low $(\sim 5 \%)$, the main product was diethyl ether with traces of acetaldehyde and ethylene. The selectivity for ethylene increased between 400 and $600 \mathrm{~K}$, and in the medium temperature range of $650-800 \mathrm{~K}$ only ethylene was detected. The lack of O-containing products in this temperature range indicates that, in spite of the presence of a substantial amount of $\mathrm{H}_{2} \mathrm{O}$ in the reaction feed, water also must be a major reaction product, originating from the dehydration reaction, which yields ethylene, too. Above $850 \mathrm{~K}$, ethylene was still the dominant species, but $\mathrm{H}_{2}, \mathrm{CO}, \mathrm{CH}_{4}$, acetaldehyde, and a small amount of $\mathrm{CO}_{2}$ were also formed.

On $\mathrm{Co} / \mathrm{SiO}_{2}$, below $650 \mathrm{~K}$ only acetaldehyde was formed. At higher temperatures, $\mathrm{H}_{2}, \mathrm{CO}, \mathrm{CH}_{4}, \mathrm{CO}_{2}$, and traces of ethylene were also detected, whereas the selectivity for acetaldehyde decreased. The selectivities for $\mathrm{H}_{2}, \mathrm{CO}$, and $\mathrm{CO}_{2}$ increased with temperature and exhibited a maximum at $900 \mathrm{~K}$, although the selectivity for $\mathrm{CH}_{4}$ monotonously increased up to $1100 \mathrm{~K}$. Above $850 \mathrm{~K}$, the main products were hydrogen, $\mathrm{CO}, \mathrm{CO}_{2}$, and methane.

For the $\mathrm{CeO}_{2}$ support (without cobalt), initially only acetaldehyde was formed, but between 650 and $850 \mathrm{~K}$, the main product was ethylene. From 700 to $900 \mathrm{~K}$, other products such as acetone, hydrogen, $\mathrm{CO}_{2}, \mathrm{CO}, \mathrm{CH}_{4}$, ethane, and ethylene were formed. Above $900 \mathrm{~K}$, hydrogen, $\mathrm{CO}_{2}$, ethylene, and smaller amounts of $\mathrm{CO}$ and methane were detected.

On $2 \% \mathrm{Co} / \mathrm{CeO}_{2}$, at low conversion up to $500 \mathrm{~K}$, acetaldehyde and acetone were detected. From 500 to $700 \mathrm{~K}$, the acetaldehyde selectivity attenuated the selectivities for $\mathrm{H}_{2}$ and ethylene, and $\mathrm{CO}_{2}$ increased moderately; however, the main carbon-containing product still was acetone. Above $700 \mathrm{~K}$, the minimum observed in the conversion and the $\mathrm{H}_{2}$ selectivity in Figure 3 at $\sim 800 \mathrm{~K}$ was mirrored as an increase to a relative maximum for the acetaldehyde selectivity at $\sim 800 \mathrm{~K}$. Above 


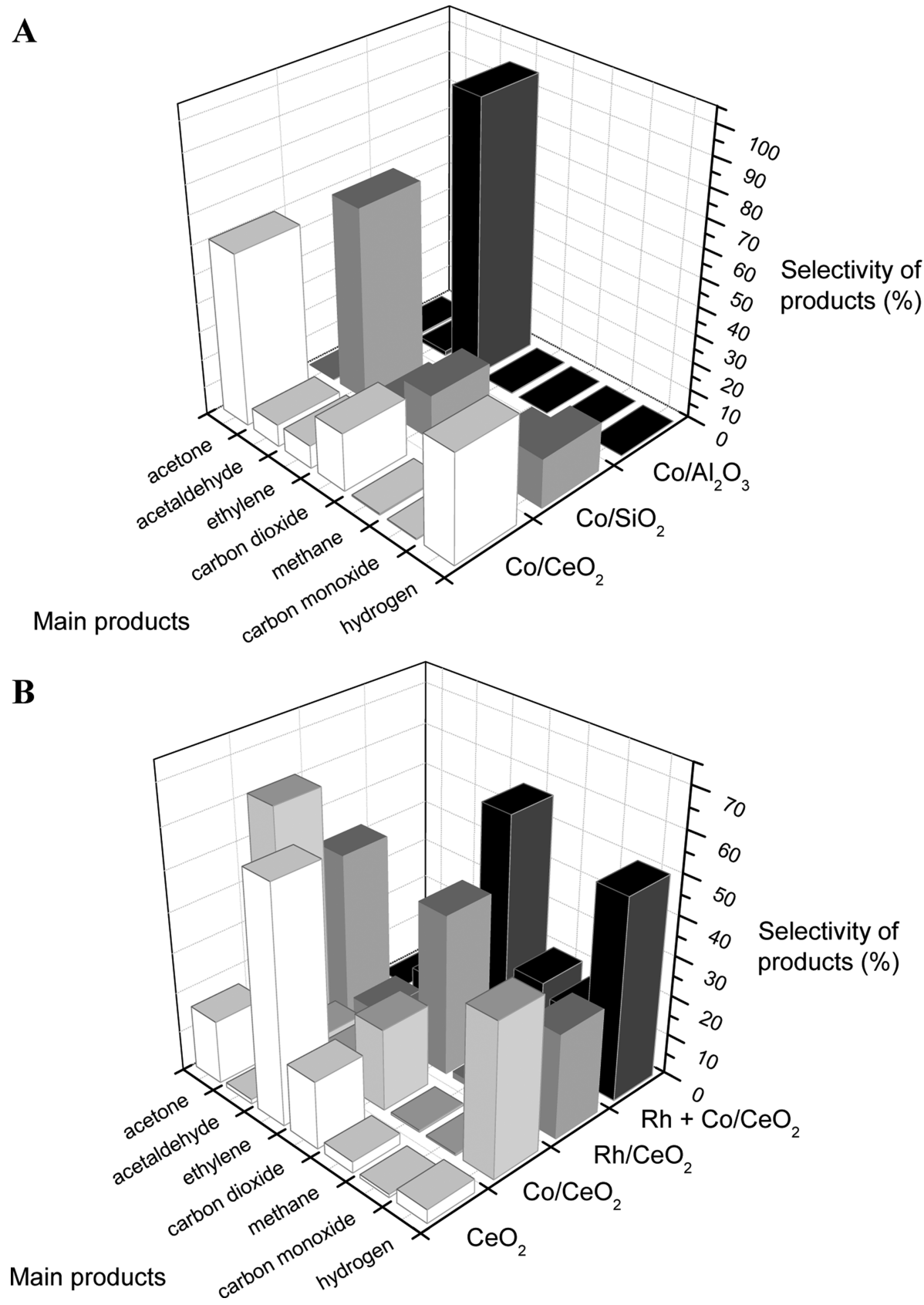

Figure 5. Product distribution in the $\mathrm{EtOH}+\mathrm{H}_{2} \mathrm{O}$ (1:3) reaction at $723 \mathrm{~K}$ on different oxide-supported Co catalysts (A) and on Co- and Rhcontaining ceria-based catalysts (B). Data are plotted at $100 \mathrm{~min}$ of reaction time.

$800 \mathrm{~K}$, the main products were $\mathrm{H}_{2}$, acetaldehyde (only up to $900 \mathrm{~K}$ ), ethylene, $\mathrm{CO}_{2}, \mathrm{CO}$, and methane. The main effect of $\mathrm{Co}$ as compared to the pure $\mathrm{CeO}_{2}$ case was manifested in the medium temperature range $(650-750 \mathrm{~K})$ as the increased conversion, accompanied by enhanced selectivities for acetone and $\mathrm{H}_{2}$ at the expense of ethylene.

On the Rh-promoted $\mathrm{Co} / \mathrm{CeO}_{2}$ catalyst, below $550 \mathrm{~K}$ the products were acetaldehyde, methane, and CO. Between 600 and $800 \mathrm{~K}$, hydrogen, methane, $\mathrm{CO}, \mathrm{CO}_{2}$, and acetaldehyde were detected, and above $800 \mathrm{~K}$, hydrogen and $\mathrm{CO}_{2}$ were dominant, but $\mathrm{CH}_{4}$ and $\mathrm{CO}$ as well as small amounts of ethylene and acetaldehyde were also formed.

For $0.1 \% \mathrm{Rh} / \mathrm{CeO}_{2}$ (without $\mathrm{Co}$ ), initially acetaldehyde and small amounts of $\mathrm{CO}$ and methane were formed, but between 650 and $750 \mathrm{~K}$, the main products were hydrogen, acetone, and
$\mathrm{CO}_{2}$. Above $850 \mathrm{~K}$, hydrogen and $\mathrm{CO}_{2}$ were the main products, with $\mathrm{CO}$, methane, and ethylene as minorities. It is worth emphasizing that acetone was not detected at any temperatures on the Rh-promoted $\mathrm{Co} / \mathrm{CeO}_{2}$ catalyst, in spite of the fact that around $700 \mathrm{~K}$ it was the major hydrocarbon product adsorbed on $2 \% \mathrm{Co} / \mathrm{CeO}_{2}$ and on $0.1 \% \mathrm{Rh} / \mathrm{CeO}_{2}$, and it was easily detectable even on $\mathrm{CeO}_{2}$ at the same temperature.

To obtain additional information, time-dependent isothermal measurements were carried out at $723 \mathrm{~K}$. Figure 4A displays the ethanol conversion as a function of reaction time, and Figure $4 \mathrm{~B}$ shows the hydrogen selectivity of the different Cosupported catalysts. The values obtained after $100 \mathrm{~min}$ of reaction time largely agree with the conversion and $\mathrm{H}_{2}$ selectivity data obtained in the TP measurement (Figure 3). At this selected intermediate temperature, the initial ethanol 
Table 2. Vibrational Frequencies for Adsorbed Molecules and Intermediates Formed in Ethanol Steam Reforming on Different Oxide-Supported Co Catalysts

\begin{tabular}{|c|c|c|c|c|c|c|c|c|}
\hline & & $\mathrm{Co} / \mathrm{Al}_{2} \mathrm{O}_{3}$ & $\mathrm{Co} / \mathrm{SiO}_{2}$ & $\mathrm{CeO}_{2}$ & $\mathrm{Co} / \mathrm{CeO}_{2}$ & $\mathrm{Rh}-\mathrm{Co} / \mathrm{CeO}_{2}$ & $\mathrm{Rh} / \mathrm{CeO}_{2}$ & \\
\hline adsorbed species & vibrational mode & & & & $\mathrm{cm}^{-1}$ & & & refs \\
\hline ethanol & $\delta(\mathrm{OH})$ & 1274 & (1299) & & 1269 & & & $\begin{array}{l}{[14] \mathrm{Ir} / \mathrm{Al}_{2} \mathrm{O}_{3}} \\
{[15] \mathrm{Pd} / \mathrm{CeO}_{2}} \\
{[77] \mathrm{Au} / \mathrm{CeO}_{2}}\end{array}$ \\
\hline water & $\delta\left(\mathrm{H}_{2} \mathrm{O}\right)$ & 1641 & & 1640 & 1621 & & 1650 & $\begin{array}{l}{[9] \mathrm{Co} / \mathrm{CeO}_{2}} \\
{[35] \mathrm{Pt} / \mathrm{Al}_{2} \mathrm{O}_{3}} \\
{[14] \mathrm{Ir} / \mathrm{Al}_{2} \mathrm{O}_{3}}\end{array}$ \\
\hline ethoxide & $\nu_{\text {as }}\left(\mathrm{CH}_{3}\right)$ & 2976 & 2979 & 2966 & 2975 & 2975 & 2973 & $\begin{array}{l}{[9] \mathrm{Co} / \mathrm{CeO}_{2}} \\
{[62] \mathrm{Pt} / \mathrm{Al}_{2} \mathrm{O}_{3}} \\
{[15,69] \mathrm{CeO}_{2}}\end{array}$ \\
\hline ethoxide & $\nu_{\text {as }}\left(\mathrm{CH}_{2}\right)$ & 2929 & 2934 & 2914 & 2926 & & & $\begin{array}{l}{[9] \mathrm{Co} / \mathrm{CeO}_{2}} \\
{[15,69] \mathrm{CeO}_{2}}\end{array}$ \\
\hline ethoxide & $\nu_{s}\left(\mathrm{CH}_{3}\right)$ & 2898 & 2898 & 2878 & 2861 & 2883 & 2886 & $\begin{array}{l}{[15,69] \mathrm{CeO}_{2}} \\
{[62] \mathrm{Pt} / \mathrm{Al}_{2} \mathrm{O}_{3}}\end{array}$ \\
\hline ethoxide & $\delta_{\text {as }}\left(\mathrm{CH}_{3}\right)$ & 1447 & 1455 & & & 1450 & & $\begin{array}{l}{[15] \mathrm{CeO}_{2}} \\
{[62] \mathrm{Pt} / \mathrm{Al}_{2} \mathrm{O}_{3}}\end{array}$ \\
\hline ethoxide & $\delta_{s}\left(\mathrm{CH}_{3}\right)$ & 1390 & 1390 & 1382 & 1395 & 1402 & 1390 & $\begin{array}{l}{[15] \mathrm{CeO}_{2}} \\
{[62] \mathrm{Pt} / \mathrm{Al}_{2} \mathrm{O}_{3}}\end{array}$ \\
\hline ethoxide & $\nu(\mathrm{CO})_{\text {mono }}$ & 1095 & 1069 & 1100 & 1100 & 1085 & 1101 & $\begin{array}{l}{[9] \mathrm{Co} / \mathrm{CeO}_{2}} \\
{[62] \mathrm{Pt} / \mathrm{Al}_{2} \mathrm{O}_{3}}\end{array}$ \\
\hline ethoxide & $\nu(\mathrm{CO})_{\mathrm{bi}}$ & 1046 & 1049 & 1056 & 1057 & 1046 & 1052 & $\begin{array}{l}{[9] \mathrm{Co} / \mathrm{CeO}_{2}} \\
{[62] \mathrm{Pt} / \mathrm{Al}_{2} \mathrm{O}_{3}}\end{array}$ \\
\hline acetalde- hyde & $\nu(\mathrm{CO})$ & 1745 & & & 1714 & 1752 & & $\begin{array}{l}{[36] \mathrm{Al}_{2} \mathrm{O}_{3}} \\
{[62] \mathrm{Pt} / \mathrm{Al}_{2} \mathrm{O}_{3}} \\
{[72] \mathrm{Co} / \mathrm{CeO}_{2}}\end{array}$ \\
\hline acetate & $\nu_{\mathrm{as}}(\mathrm{OCO})$ & 1567 & 1550 & 1559 & 1565 & 1552 & 1560 & $\begin{array}{l}{[15,69] \mathrm{CeO}_{2}} \\
{[75] \mathrm{Au} / \mathrm{CeO}_{2}}\end{array}$ \\
\hline acetate & $\nu_{\mathrm{s}}(\mathrm{OCO})$ & 1452 & & 1427 & 1433 & 1430 & 1425 & $\begin{array}{l}{[9] \mathrm{Co} / \mathrm{CeO}_{2}} \\
{[62] \mathrm{Pt} / \mathrm{Al}_{2} \mathrm{O}_{3}} \\
{[77] \mathrm{Au} / \mathrm{CeO}_{2}}\end{array}$ \\
\hline acetate & $\delta_{\mathrm{s}}\left(\mathrm{CH}_{3}\right)$ & 1338 & & 1333 & 1330 & 1343 & 1335 & $\begin{array}{l}{[9] \mathrm{Co} / \mathrm{CeO}_{2}} \\
{[69] \mathrm{CeO}_{2}}\end{array}$ \\
\hline $\mathrm{CO}$ & linear & & & & & 2045 & & [7] $\mathrm{Rh} / \mathrm{CeO}_{2}$ \\
\hline $\mathrm{CO}$ & bridge & & & & & & 1980 & [7] $\mathrm{Rh} / \mathrm{CeO}_{2}$ \\
\hline croton-aldehyde & $\begin{array}{l}\nu(\mathrm{C}=\mathrm{O}) \\
\nu(\mathrm{C}=\mathrm{C})\end{array}$ & & & & 1606 & 1614 & 1611 & $\begin{array}{l}{[15] \mathrm{Pd} / \mathrm{CeO}_{2}} \\
{[71] \mathrm{Pt} / \mathrm{CeO}_{2}} \\
{[77] \mathrm{Au} / \mathrm{CeO}_{2}}\end{array}$ \\
\hline carbonate & $\nu(\mathrm{OCO})$ & & & 1485 & 1506 & 1466 & 1507 & {$[70] \mathrm{CeO}_{2}$} \\
\hline carbonate & $\nu(\mathrm{OCO})$ & & & 1389 & & 1338 & & {$[70] \mathrm{CeO}_{2}$} \\
\hline
\end{tabular}

conversion was $\sim 80-95 \%$ on the alumina and ceria supports, although on $\mathrm{Co} / \mathrm{SiO}_{2}$ it was only $\sim 50 \%$. It is apparent from Figure 4 that the addition of $\mathrm{Rh}$ to $\mathrm{Co} / \mathrm{CeO}_{2}$ not only increased the rate for $\mathrm{H}_{2}$ production but also enhanced the stability of the catalyst. The corresponding product distribution can be seen in Figure 5: panel A shows the products on $\mathrm{Al}_{2} \mathrm{O}_{3}$, $\mathrm{SiO}_{2}$, and $\mathrm{CeO}_{2}$-supported Co catalysts, and panel $\mathrm{B}$ represents the product distribution only on ceria-based catalysts. We plotted average data at $100 \mathrm{~min}$ reaction time. The measured values are also listed in the Supporting Information (Table S1). On $\mathrm{Co} / \mathrm{Al}_{2} \mathrm{O}_{3}$, only ethylene was detected at this temperature. $\mathrm{On} \mathrm{Co} / \mathrm{SiO}_{2}$, mainly acetaldehyde, hydrogen, carbon monoxide, and carbon dioxide were formed, along with small amounts of methane, ethylene, and traces of ethyl acetate. On $\mathrm{Co} / \mathrm{CeO}_{2}$, predominantly acetone, $\mathrm{H}_{2}$, and $\mathrm{CO}_{2}$ were formed, plus small amounts of $\mathrm{CO}$, ethylene, and acetaldehyde. For the Rh-modified $\mathrm{Co} / \mathrm{CeO}_{2}$ catalyst, hydrogen and $\mathrm{CO}_{2}$ are dominant, but $\mathrm{CH}_{4}, \mathrm{CO}$, and a small amount of acetaldehyde were also formed. The product selectivity was rather stable after
100 min of reaction time. Also for pure $\mathrm{CeO}_{2}$, a catalytic activity was observed, yielding $\mathrm{C}_{2} \mathrm{H}_{4}, \mathrm{CO}_{2}$, acetone, and small amounts of $\mathrm{H}_{2}$; the conversion of ethanol was only $25 \%$, whereas it was $\sim 80 \%$ on $2 \% \mathrm{Co} / \mathrm{CeO}_{2}$. Adding a small amount of $\mathrm{Rh}$ without Co led to a much higher activity compared to pure ceria, and the main products were acetone, $\mathrm{CO}_{2}$, and $\mathrm{H}_{2}$.

In order to point out the efficiency of the $0.1 \% \mathrm{Rh}$ promoter, we performed some experiments with a $\mathrm{Rh}$-free $10 \% \mathrm{Co} / \mathrm{CeO}_{2}$ catalyst (Figure 4A,B and Table S1). It is clearly shown that the effect of $0.1 \% \mathrm{Rh}$ is more significant than the increase in Co loading in terms of both conversion and selectivity.

The amount and type of carbon formed in catalytic ethanol steam reforming is an important issue. In agreement with earlier findings, ${ }^{22}$ carbon deposits were formed covering both support and cobalt particles, regardless of the type of support used. The extent of coke formation and probably its surface structure depended on the support. After $120 \mathrm{~min}$ of reaction at $823 \mathrm{~K}$, the highest quantity, $460 \mu \mathrm{mol} / \mathrm{g}$ of deposited carbon, was determined on $\mathrm{Co} / \mathrm{SiO}_{2}$, and $344 \mu \mathrm{mol} / \mathrm{g}$ on $\mathrm{Co} / \mathrm{CeO}_{2}$ 
and $55 \mu \mathrm{mol} / \mathrm{g}$ on $\mathrm{Co} / \mathrm{Al}_{2} \mathrm{O}_{3}$ were found. Interestingly, although Rh-promoted $\mathrm{Co} / \mathrm{CeO}_{2}$ showed the highest and most stable hydrogen selectivity, the amount of surface carbon, $1135 \mu \mathrm{mol} / \mathrm{g}$, was higher than that on $\mathrm{Co} / \mathrm{CeO}_{2}$. Previous studies suggested that carbon buildup does not necessarily lead to deactivation ${ }^{6,62,63}$

3.4. Infrared Spectra during Ethanol Steam Reforming at Elevated Temperatures. For catalytic reactions, the exploration of surface species formed during the catalytic processes plays a decisive role in the understanding of the reaction mechanism. Toward this goal, DRIFT spectra were taken at increasing reaction temperatures, in the presence of the reactant mixture/products. The assignment of IR bands and the detailed description is based on the vibrational fingerprints of relevant surface species, which were reported in previous publications. ${ }^{19,33-36,64-66}$ The IR bands obtained during the present work and their origin are collected in Table 2. Note that the denoted wave numbers may vary as function of temperature by $\pm 5 \mathrm{~cm}^{-1}$ within one data set. In the following, we will discuss the DRIFT spectra for the different catalysts presented in Figures 6-8; the deduced reactions pathways for all catalysts are summarized in Scheme 1.
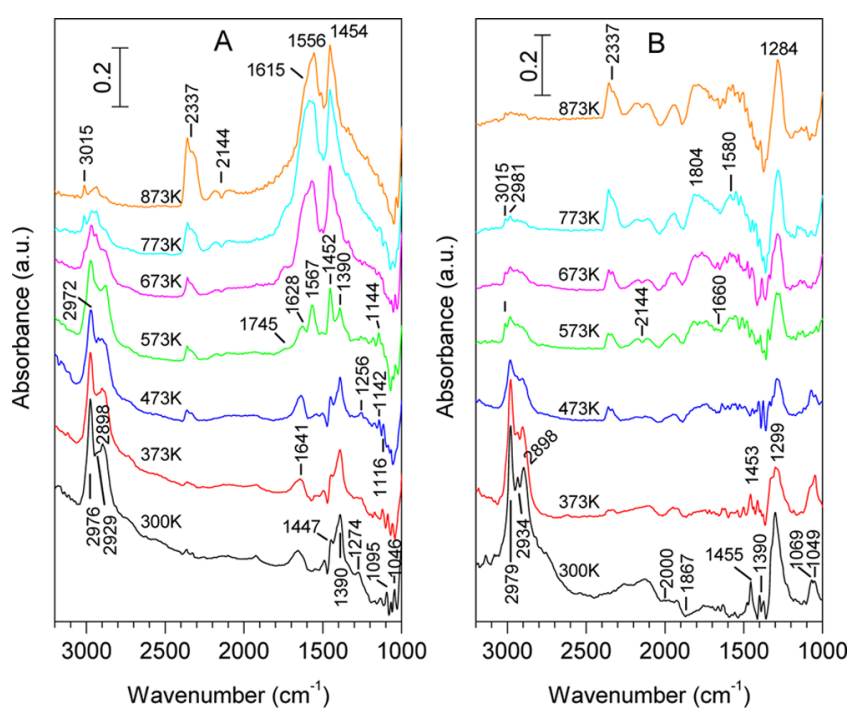

Figure 6. DRIFT spectra obtained during linear heating $(20 \mathrm{~K} / \mathrm{min})$ in ethanol-water mixture $(1: 3)$ on $2 \% \mathrm{Co} / \mathrm{Al}_{2} \mathrm{O}_{3}(\mathrm{~A})$ and on $2 \% \mathrm{Co} /$ $\mathrm{SiO}_{2}$ (B) catalyst.

It is generally accepted that in ethanol transformation reactions, the first step is the formation of adsorbed ethoxide $\left(\mathrm{C}_{2} \mathrm{H}_{5} \mathrm{O}_{(\mathrm{ads})}\right)$, according to reaction $1:{ }^{6,30,35}$

$$
\mathrm{C}_{2} \mathrm{H}_{5} \mathrm{OH} \rightarrow \mathrm{C}_{2} \mathrm{H}_{5} \mathrm{O}_{(\mathrm{ads})}+\mathrm{H}_{(\mathrm{ads})}
$$

The resulting adsorbed $\mathrm{H}$ can form $\mathrm{OH}$ groups with lattice $\mathrm{O}$ or possibly $\mathrm{H}_{2} \mathrm{O}_{(\mathrm{a})}$ with surface $\mathrm{OH}$ species.

On $\mathrm{Co} / \mathrm{Al}_{2} \mathrm{O}_{3}$, the corresponding DRIFTS spectra in Figure 6A show characteristic peaks in the $\mathrm{CH}$ stretching frequency range at 2976, 2929, and $2898 \mathrm{~cm}^{-1}$, which are assigned to the $\nu_{\text {as }}\left(\mathrm{CH}_{3}\right), \quad \nu_{\text {as }}\left(\mathrm{CH}_{2}\right)$, and $\nu_{\mathrm{s}}\left(\mathrm{CH}_{3}\right)$ modes of ethoxide, respectively; the $\nu_{s}\left(\mathrm{CH}_{2}\right)$ mode probably overlaps with the $\nu_{s}\left(\mathrm{CH}_{3}\right)$ mode $2898 \mathrm{~cm}^{-1}$. At room temperature, the comparably weak bands of mono- and bidentate ethoxide, $\nu(\mathrm{CO})_{\text {mono }}$ and $\nu(\mathrm{CO})_{\text {bi }}$ can be identified at 1095 and 1046 $\mathrm{cm}^{-1}$ and also the $\delta_{\text {as }}\left(\mathrm{CH}_{3}\right)$ and $\delta_{\mathrm{s}}\left(\mathrm{CH}_{3}\right)$ bands at around 1447 and $1390 \mathrm{~cm}^{-1}$, respectively-see Table 2 . The ethoxy bands decrease with increasing temperature. Our catalytic measurements on $\mathrm{Co} / \mathrm{Al}_{2} \mathrm{O}_{3}$ showed that at $650-800 \mathrm{~K}$ the dominant reaction product in the gas phase is ethylene. The Lewis acid-base pairs present on the alumina support are expected to facilitate the dehydration of ethanol (ethoxide) via an $E_{2}$ mechanism. ${ }^{6,67}$ Thus, the specific choice of the metal should not alter the reaction paths significantly, and indeed, similar intermediates and products were detected on $\mathrm{Pt}^{35,64}$ or $\mathrm{Ir}^{14}$ supported on alumina, with the only difference being the absence of adsorbed $\mathrm{CO}_{(\mathrm{ads})}$ in our study (with bands expected between 1950 and $2120 \mathrm{~cm}^{-1}$ ). The dehydration of ethanol to ethylene presumably occurs at least partly via a two-step dehydration: ${ }^{6}$

$$
\begin{aligned}
& 2 \mathrm{C}_{2} \mathrm{H}_{5} \mathrm{OH} \rightarrow \mathrm{C}_{2} \mathrm{H}_{5} \mathrm{OC}_{2} \mathrm{H}_{5}+\mathrm{H}_{2} \mathrm{O} \\
& \mathrm{C}_{2} \mathrm{H}_{5} \mathrm{OC}_{2} \mathrm{H}_{5} \rightarrow 2 \mathrm{C}_{2} \mathrm{H}_{4}+\mathrm{H}_{2} \mathrm{O}
\end{aligned}
$$

The first step (Reaction 2) involves the formation of diethyl ether $\left(\mathrm{C}_{2} \mathrm{H}_{5} \mathrm{OC}_{2} \mathrm{H}_{5}\right)$ as a result of intermolecular dehydration from two ethanol molecules. This is followed by a second dehydration of diethyl ether to ethylene (Reaction 3). Indeed, at low temperatures $(<550 \mathrm{~K})$ and low conversion diethyl ether is the dominating product in gas phase. At higher temperatures, its conversion to ethylene is very fast, and ethylene is the only product in gas phase. However, we cannot rule out the occurrence of monomolecular dehydration, as it was deduced in DFT calculations ${ }^{68}$

During the reaction of the ethanol-water mixture, chemisorbed water led to the $\delta(\mathrm{OH})$ band at $1641 \mathrm{~cm}^{-1}$ (Figure 6A), similar to previous observations on $\mathrm{Co} / \mathrm{CeO}_{2}{ }^{9}$ and on $\mathrm{Pt}^{35}$ or $\mathrm{Ir}^{14}$ supported by alumina. The $1274 \mathrm{~cm}^{-1}$ band observed at $300 \mathrm{~K}$ was attributed to the $\delta(\mathrm{OH})$ mode of molecularly adsorbed ethanol and was detectable up to $573 \mathrm{~K}$. Molecular ethanol was previously also detected on $\mathrm{Al}_{2} \mathrm{O}_{3}$ and $\mathrm{Ir} / \mathrm{Al}_{2} \mathrm{O}_{3}$ up to $623 \mathrm{~K}^{14}$ The assignment of this peak to molecular ethanol is corroborated by the fact that it was very weak, when ethoxide species were produced from $\mathrm{C}_{2} \mathrm{H}_{5} \mathrm{I}$ on $\mathrm{Al}_{2} \mathrm{O}_{3}{ }^{66}$ Molecular ethanol also slightly contributes to the peaks in the $\mathrm{CH}$ stretch region and to the low wavenumber peaks of ethoxide.

The adsorbed ethoxy species to a certain extent can further dehydrogenate to acetaldehyde $\left(\mathrm{CH}_{3} \mathrm{CHO}_{(\mathrm{ads})}\right.$ - Reaction 4 . We tentatively assign the weak peak at $1745 \mathrm{~cm}^{-1}$ above $550 \mathrm{~K}$ to the $\nu(\mathrm{CO})$ band in acetaldehyde. ${ }^{36,65}$ Furthermore, as shown in the Supporting Information, at low temperatures a small amount of acetaldehyde was detected in gas phase by GC between 350 and $500 \mathrm{~K}$.

$$
\begin{aligned}
& \mathrm{C}_{2} \mathrm{H}_{5} \mathrm{O}_{(\mathrm{ads})} \rightarrow \mathrm{CH}_{3} \mathrm{CHO}_{(\mathrm{ads})}+\mathrm{H}_{(\mathrm{ads})} \\
& \mathrm{CH}_{3} \mathrm{CHO}_{(\mathrm{ads})}+\mathrm{OH}_{(\mathrm{ads})} \rightarrow \mathrm{CH}_{3} \mathrm{COO}_{(\mathrm{ads})}+\mathrm{H}_{2} \\
& \mathrm{CH}_{3} \mathrm{CHO}_{(\mathrm{ads})}+2 \mathrm{O}_{(\mathrm{lat})} \rightarrow \mathrm{CH}_{3} \mathrm{COO}_{(\mathrm{ads})}+\mathrm{OH}_{(\mathrm{ads})}
\end{aligned}
$$

Acetaldehyde can be transformed in different ways: it can desorb from the surface above $850 \mathrm{~K}$ (see SI), decompose to gas phase methane and $\mathrm{CO}$, or react with hydroxyl groups or with lattice oxygen to form acetate $\left(\mathrm{CH}_{3} \mathrm{COO}_{(\mathrm{ads})}\right.$ - Reactions 5 and 6). ${ }^{36,64,65}$ This stable species is characterized by the $\nu_{\mathrm{s}}(\mathrm{OCO})$ and $\nu_{\text {as }}(\mathrm{OCO})$ bands at 1452 and $1567 \mathrm{~cm}^{-1}$ (e.g., at $573 \mathrm{~K}$ in Figure 6A), respectively. Its decomposition products at higher temperatures are volatile methane $\left(\nu_{\text {as }}(\mathrm{CH}), 3015\right.$ $\left.\mathrm{cm}^{-1}\right)$ and $\mathrm{CO}_{2}\left(\nu_{\mathrm{as}}(\mathrm{O}=\mathrm{C}=\mathrm{O}), 2337 \mathrm{~cm}^{-1}\right)$, observed by IR 
Scheme 1. Reaction Pathways of SRE on Different Oxide-Supported Co Catalysts (Main Routes Are Colored Red)
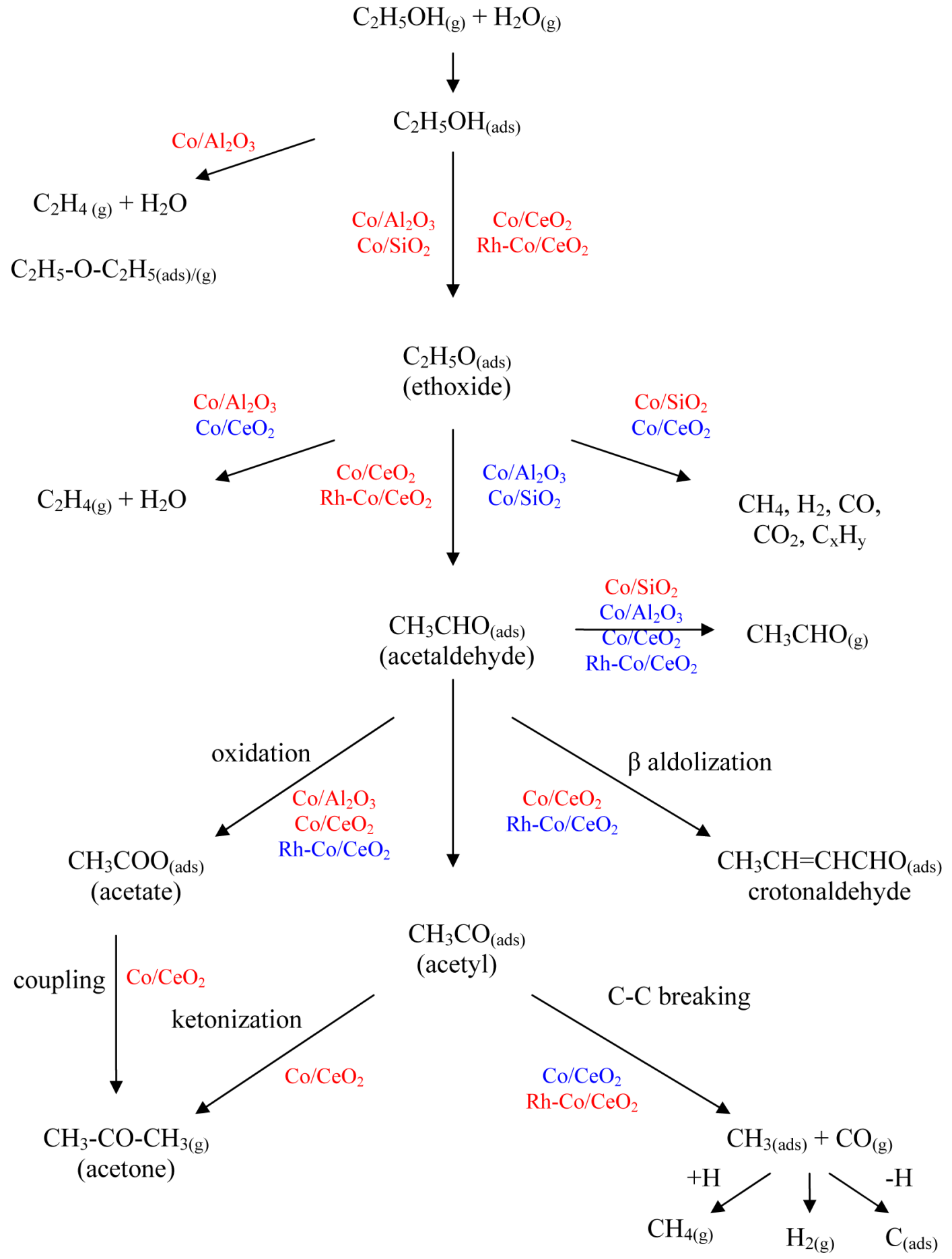

in the gas phase. The proposed reaction pathway is included in Scheme 1.

The DRIFT spectra for $2 \% \mathrm{Co} / \mathrm{SiO}_{2}$ in the ethanol-water mixture are shown in Figure 6B. The bands at 1069 and 1049 $\mathrm{cm}^{-1}$ were assigned to the $\nu(\mathrm{CO})$ vibrations of mono- and bidentate ethoxide; the peaks at 1455 and $1390 \mathrm{~cm}^{-1}$ are attributed to the ethoxide $\delta_{\text {as }}\left(\mathrm{CH}_{3}\right)$ and $\delta_{\mathrm{s}}\left(\mathrm{CH}_{3}\right)$ modes, and the peaks at 2979,2934 , and $2898 \mathrm{~cm}^{-1}$ to the ethoxide $\nu_{\text {as }}\left(\mathrm{CH}_{3}\right), \nu_{\text {as }}\left(\mathrm{CH}_{2}\right)$, and $\nu_{s}\left(\mathrm{CH}_{3}\right)$ modes, respectively. In addition, molecular ethanol may also contribute to the abovementioned bands. The evaluation of the low wavenumber region of $\mathrm{Co} / \mathrm{SiO}_{2}$ is particularly difficult, because $\mathrm{SiO}_{2}$ itself has very strong absorptions at $\sim 2000, \sim 1870$, and $\sim 1640 \mathrm{~cm}^{-1}$, and a sharp absorption edge at $\sim 1300 \mathrm{~cm}^{-1}$. Although these features should be accounted for by the background spectrum, they might also change as a function of temperature and thus disturb our spectra. We tentatively assign the features observed at $2000,1867,1660 \mathrm{~cm}^{-1}$, and also the intense peak at 1299 $\mathrm{cm}^{-1}$ to this effect. The alternative assignment of the $1299 \mathrm{~cm}^{-1}$ peak to molecular ethanol (as it was done for $\mathrm{Co} / \mathrm{Al}_{2} \mathrm{O}_{3}$ ) would imply its presence in large amounts on the surface up to $873 \mathrm{~K}$, which is highly unlikely. Upon heating, the ethoxide bands decreased in intensity and disappeared around $573 \mathrm{~K}$. According to our kinetics measurements (Figure 3A), practi- 
cally no conversion occurred up to $600 \mathrm{~K}$; only a small amount of acetaldehyde was detected. Above $650 \mathrm{~K}$, besides the continuously decreasing acetaldehyde, hydrogen and $\mathrm{CO}$ are the main products in the gas phase. Because $\mathrm{SiO}_{2}$ is rather inert, surface transformations probably mostly occur on metallic/ oxidized Co. Beside acetaldehyde formation (Reaction 4), the primary pathway on $\mathrm{Co}^{0}$ sites is decarbonylation (Reaction 7), in agreement with the observation on pure metallic cobalt: ${ }^{41}$

$$
\mathrm{C}_{2} \mathrm{H}_{5} \mathrm{O}_{(\mathrm{ads})} \rightarrow 2 \mathrm{H}_{2}+\mathrm{CO}_{(\mathrm{ads})}+\mathrm{C}_{(\text {ads })}
$$

Before discussing the results obtained during heating the $\mathrm{Co} /$ $\mathrm{CeO}_{2}$ system in ethanol-water mixture, we briefly summarize the most important findings on clean ceria. Even though the interaction of ethanol and ethanol-water mixtures with $\mathrm{CeO}_{2}$ was previously studied by other authors ${ }^{15,69}$ using IR spectroscopy, we repeated some measurements to have direct comparison with data obtained in the same apparatus. In these experiments, the ethoxide bands were found at 2966, 2914, $2878,1382,1100,1056$, and $905 \mathrm{~cm}^{-1}$, up to $573 \mathrm{~K}$ (Figure $7 \mathrm{~A}$,

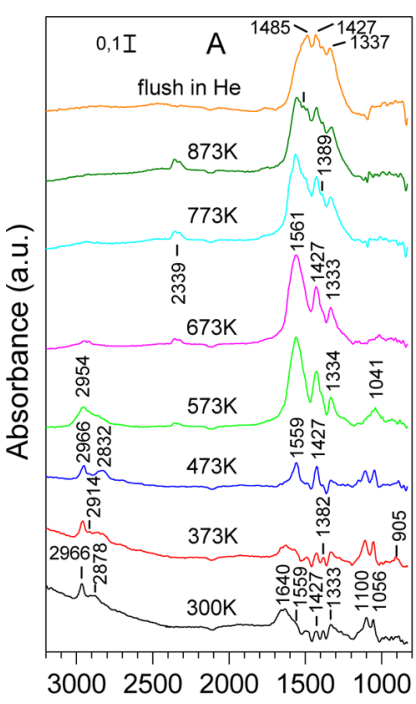

Wavenumber $\left(\mathrm{cm}^{-1}\right)$

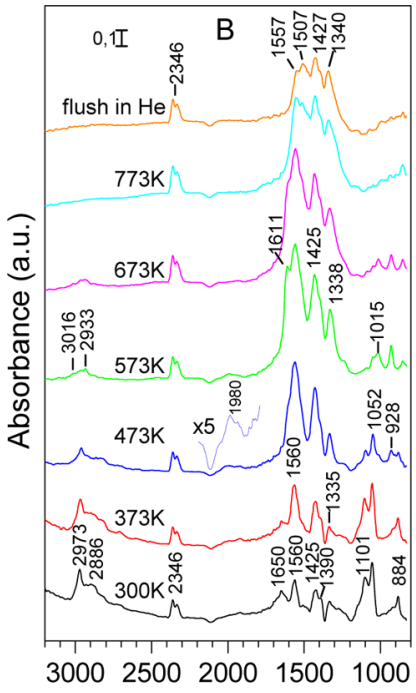

Wavenumber $\left(\mathrm{cm}^{-1}\right)$
Figure 7. DRIFT spectra obtained during linear heating $(20 \mathrm{~K} / \mathrm{min})$ in ethanol-water mixture $(1: 3)$ on $\mathrm{CeO}_{2}(\mathrm{~A})$ and on $0.1 \% \mathrm{Rh} / \mathrm{CeO}_{2}$ catalyst (B). The insert of the $\mathrm{CO}$ regime at $473 \mathrm{~K}$ is magnified by 5 .

Table 2). The formation of an acetaldehyde surface species was not observed. These observations are in agreement with recent photoelectron spectroscopic results obtained for ethanol adsorption at low $^{38}$ or higher pressures ${ }^{43}$ on well-ordered $\mathrm{CeO}_{2}(111)$ films. The peak at $1640 \mathrm{~cm}^{-1}$ is assigned to $\mathrm{H}_{2} \mathrm{O}_{(\mathrm{a}}$, which is stable up to $373 \mathrm{~K}$. Upon heating, starting at $473 \mathrm{~K}$, the peaks of acetate species dominated the spectrum (1559, 1427 , and $\left.1334 \mathrm{~cm}^{-1}\right)$. Please note that minor amounts of this species are already formed at $300 \mathrm{~K}^{20,69}$ Starting from $773 \mathrm{~K}$, the acetate groups transformed at least partly into carbonate, as indicated by the peaks at 1485 and $1389 \mathrm{~cm}^{-1}$, wavenumbers typical for carbonates. ${ }^{70}$ Because the formation of carbonates from acetate is accompanied by slight shifts of the acetate bands, ${ }^{15,71}$ it is difficult to determine if any acetate remains on the surface after this process. Nevertheless, the (almost) complete lack of $\mathrm{C}-\mathrm{H}$ stretching features at $\mathrm{T} \geq 773 \mathrm{~K}$ suggests that the amount of acetate is rather small (note that for $\mathrm{Co} / \mathrm{Al}_{2} \mathrm{O}_{3}$ the high thermal stability of acetate groups was accompanied by easily detectable $\mathrm{C}-\mathrm{H}$ stretch modes up to $873 \mathrm{~K}$ (Figure 6A).

The DRIFTS measurements of the $2 \% \mathrm{Co} / \mathrm{CeO}_{2}$ catalyst in the ethanol-water mixture from 300 to $873 \mathrm{~K}$ are shown in Figure $8 \mathrm{~A}$. The assignment of the peaks was based on previous
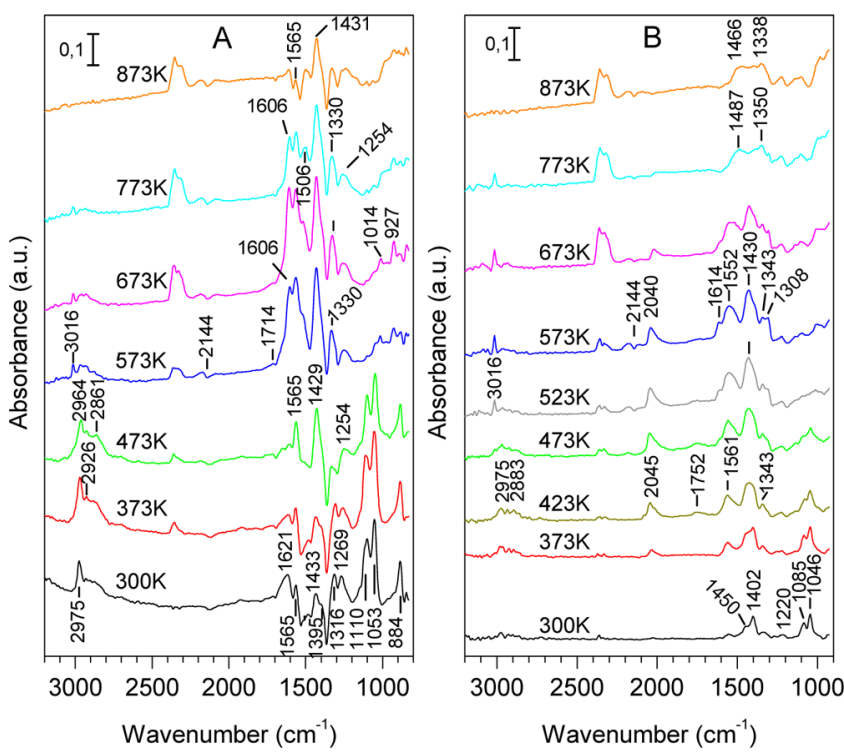

Figure 8. DRIFT spectra obtained during linear heating $(20 \mathrm{~K} / \mathrm{min})$ in ethanol-water mixture $(1: 3)$ on $2 \% \mathrm{Co} / \mathrm{CeO}_{2}(\mathrm{~A})$ and on $0.1 \% \mathrm{Rh}$ $+2 \% \mathrm{Co} / \mathrm{CeO}_{2}$ catalyst (B).

works. $^{6,9-11,15,28,72,73}$ The formation of ethoxide (2975, 2926, $2861,1395,1100,1053$, and $884 \mathrm{~cm}^{-1}$ ) was observed after the introduction of the reaction feed at room temperature. The band at $1621 \mathrm{~cm}^{-1}$, detectable up to $473 \mathrm{~K}$, is assigned to molecular water on the surface, whereas the band at $1269 \mathrm{~cm}^{-1}$ is attributed to molecular ethanol. In addition, the formation of acetate was detected at this temperature (1565, 1433, 1316 $\mathrm{cm}^{-1}$ ). Although below $573 \mathrm{~K}$ small amounts of acetaldehyde were detected in gas phase (Supporting Information), no bands due to adsorbed acetaldehyde were observed $\left(1714 \mathrm{~cm}^{-1}\right)$ in this temperature regime. The intensity of ethoxide bands decreased significantly above $473 \mathrm{~K}$. The acetate peaks (1565, $1429,1330 \mathrm{~cm}^{-1}$ ) increased considerably up to $573 \mathrm{~K}$. It is remarkable that adsorbed $\mathrm{CO}$ was not identified in the whole temperature range.

From $\sim 500 \mathrm{~K}$ on, acetone was observed in gas phase. The vibrational frequencies of (adsorbed) acetone and acetaldehyde are very close, which renders the discrimination between the two molecules very demanding. Nevertheless, because the peak at $1714 \mathrm{~cm}^{-1}$ is very small, we conclude that the surface concentration of acetone was very low. From the gas phase product distribution at $723 \mathrm{~K}$ in Figure 5, we may conclude that on a basic support such as ceria, ethoxide is dehydrogenated yielding acetaldehyde, which is immediately oxidized to surface acetate species by lattice oxygen or by $\mathrm{OH}$ groups (Reactions 5 and 6). The other reaction path is the formation of acetone $\left(\mathrm{CH}_{3} \mathrm{COCH}_{3(\mathrm{~g})}\right)$, which is the dominant product at medium temperatures in our case. According to literature data, acetone can be produced through aldol condensation of acetate (Reaction 8) or via the reaction of acetyl groups $\left(\mathrm{CH}_{3} \mathrm{CO}\right)$ with methyl species (Reactions 9-11): ${ }^{6,72}$

$$
2 \mathrm{CH}_{3} \mathrm{COO}_{(\mathrm{ads})} \rightarrow \mathrm{CH}_{3} \mathrm{COCH}_{3(\mathrm{~g})}+\mathrm{CO}_{2}+\mathrm{O}_{(\mathrm{ads})}
$$




$$
\begin{aligned}
& \mathrm{CH}_{3} \mathrm{CHO}_{(\mathrm{ads})} \rightarrow \mathrm{CH}_{3} \mathrm{CO}_{(\mathrm{ads})}+\mathrm{H}_{(\mathrm{ads})} \\
& \mathrm{CH}_{3} \mathrm{CO}_{(\mathrm{ads})} \rightarrow \mathrm{CH}_{3(\mathrm{ads})}+\mathrm{CO} \\
& \mathrm{CH}_{3} \mathrm{CO}_{(\mathrm{ads})}+\mathrm{CH}_{3(\mathrm{ads})} \rightarrow \mathrm{CH}_{3} \mathrm{COCH}_{3(\mathrm{~g})}
\end{aligned}
$$

The high acetone production between 500 and $750 \mathrm{~K}$ suggests a propensity of the oxide phases for aldol condensation-type reactions because our catalyst contains a significant number of $\mathrm{Co}^{2+}$ sites, and ceria is still oxidized in this temperature range. We note that product distribution on $\mathrm{Co} /$ $\mathrm{CeO}_{2}$ depends on the preparation method and on the support particle size. ${ }^{11,73,74}$ In the reaction mechanism, mentioned above, the acetyl intermediate may play an important role, in spite of the fact that it could not detected by IR during the reaction due to its limited lifetime on the surface. Acetyl species were identified after adsorption of aldehyde on $\mathrm{Co} / \mathrm{CeO}_{2}$ at $1684 \mathrm{~cm}^{-1}$; this small acetyl band was only present when the aldehyde-covered surface was heated to $335 \mathrm{~K} .{ }^{72}$ The proposed pathways on $\mathrm{CeO}_{2}$-supported $\mathrm{Co}$ catalysts are included in Scheme 1.

From $573 \mathrm{~K}$ on, a new feature showed up at $1606 \mathrm{~cm}^{-1}$, and it was present up to $773 \mathrm{~K}$. We assign this band to $\nu(\mathrm{C}=\mathrm{O})$ and $\nu(\mathrm{C}=\mathrm{C})$ modes $^{73}$ of adsorbed crotonaldehyde $\left(\mathrm{CH}_{3} \mathrm{CH}=\mathrm{CHCHO}\right.$; Reaction 12). This band was also detected and attributed to crotonaldehyde formation on ceriasupported $\mathrm{Pt}^{14,35}$ and $\mathrm{Pd}^{15}$ during ethanol steam reforming reaction. The other vibrational modes of adsorbed crotonaldehyde are typically much weaker and are thus not detected. ${ }^{75}$ Such kind of four $\mathrm{C}-\mathrm{C}$ bond formation reactions can be described by $\beta$-aldolization of acetaldehyde to crotonaldehyde, as it was shown for the adsorption of acetaldehyde on ceria ${ }^{36,72}$ and on ceria-supported Co or noble metals. ${ }^{7,72}$

$2 \mathrm{CH}_{3} \mathrm{CHO}_{(\mathrm{ads})} \rightarrow \mathrm{CH}_{3} \mathrm{CH}=\mathrm{CHCHO}_{(\mathrm{ads})}+\mathrm{H}_{(\mathrm{ads})}+\mathrm{OH}_{(\mathrm{ads})}$

The formation of gas phase methane $\left(3016 \mathrm{~cm}^{-1}\right), \mathrm{CO}_{2}$ $\left(2359 \mathrm{~cm}^{-1}\right)$, and CO $\left(2144 \mathrm{~cm}^{-1}\right)$ was also detected by IR. Above $700 \mathrm{~K}$, the acetate and crotonaldehyde species decomposed, and carbonate species were detected. The band at $1506 \mathrm{~cm}^{-1}$ can certainly be assigned to $\nu$ (OCO) mode of carbonate (Figure 8A). Because different types of carbonate can coexist on the $\mathrm{CeO}_{2}$ surface with peaks partially overlapping with acetate, ${ }^{70}$ a clear distinction between these forms is ambiguous. Nevertheless, the weak intensity observed in the $\nu(\mathrm{C}-\mathrm{H})$ stretching region suggests that the surface concentration of acetate at $T \geq 773 \mathrm{~K}$ is small. The analysis of the gas phase showed methane, $\mathrm{CO}_{2}, \mathrm{CO}$, ethylene, acetaldehyde, and $\mathrm{H}_{2}$. At $\sim 800 \mathrm{~K}$, the conversion and the $\mathrm{H}_{2}$ selectivity transiently dropped, which was also seen as an increase in the acetaldehyde selectivity (Supporting Information). A possible reason is the reduced rate of the formation of acetate and acetyl from acetaldehyde, leading to acetaldehyde desorption and recombination to ethanol (Reaction 13)

$$
\mathrm{CH}_{3} \mathrm{CHO}_{(\mathrm{a})}+2 \mathrm{H}_{(\mathrm{a})} \rightarrow \mathrm{CH}_{3} \mathrm{CH}_{2} \mathrm{OH}_{(\mathrm{g})}
$$

Adding $0.1 \% \mathrm{Rh}$ to the $2 \% \mathrm{Co} / \mathrm{CeO}_{2}$ catalyst changed the stability and intensity of intermediates formed during the catalytic reaction, as is evident from the DRIFTS spectra in Figure $8 \mathrm{~B}$, which were measured in the presence of the ethanol-water reaction mixture. As established by XPS (see above), Co was transformed into a fully metallic state, and also a significant amount of $\mathrm{Ce}^{4+}$ was reduced to $\mathrm{Ce}^{3+}$ after hydrogen reduction up to $773 \mathrm{~K}$ (Figure 2). Significantly less ethoxide was detected, and it was not identified above $523 \mathrm{~K}$. However, adsorbed $\mathrm{CO}$ was established already at $373 \mathrm{~K}$ : the band at $2045 \mathrm{~cm}^{-1}$ is attributed to CO linearly bonded to $\mathrm{Rh}$ or metallic Co. ${ }^{7,76}$ From $523 \mathrm{~K}$ on, bands for gas phase methane $\left(\nu\left(\mathrm{CH}_{3}\right)\right.$ at $3016 \mathrm{~cm}^{-1}$ and $\delta\left(\mathrm{CH}_{3}\right.$ at $\left.1308 \mathrm{~cm}^{-1}\right)$ appeared, and gas phase $\mathrm{CO}_{2}\left(2359 \mathrm{~cm}^{-1}\right)$ was detected. Acetaldehyde was observed at $1752 \mathrm{~cm}^{-1}$ on this surface between 423 and $573 \mathrm{~K}$, in line with observations on $\mathrm{CeO}_{2}$-based supports with other noble metals, such as $\mathrm{Rh}^{7} \mathrm{Pt}^{71} \mathrm{Pd},{ }^{15}$ and $\mathrm{Au} .{ }^{77}$ Between 300 and $673 \mathrm{~K}$, the bands characteristic of acetate bands are detected, albeit with lower intensity than measured on $\mathrm{Co} /$ $\mathrm{CeO}_{2}$. This observation is in agreement with recent findings that $\mathrm{Rh}$ promotes the demethanation of acetate to carbonate. ${ }^{96}$ In contrast to $\mathrm{Co} / \mathrm{CeO}_{2}$, a weak band from crotonaldehyde at $1614 \mathrm{~cm}^{-1}$ only transiently showed up $(523-573 \mathrm{~K})$.

For comparison, DRIFTS measurements were also carried out on the $0.1 \% \mathrm{Rh} / \mathrm{CeO}_{2}$ catalyst, that is, without cobalt (Figure 7B). The bands characteristic of ethoxide (2973, 2886, 1390,1101 , and $1052 \mathrm{~cm}^{-1}$ ) are clearly visible at $300 \mathrm{~K}$ and decreased above $373 \mathrm{~K}$ to finally disappear around $673 \mathrm{~K}$. At room temperature, transiently adsorbed water is also detected $\left(1650 \mathrm{~cm}^{-1}\right)$. Acetate species $\left(1560,1425\right.$, and $\left.1335 \mathrm{~cm}^{-1}\right)$ were already present at $300 \mathrm{~K}$ and grew considerably upon annealing. A (partial) conversion of acetate to carbonate set in at $773 \mathrm{~K}$, as was observed also on $\mathrm{CeO}_{2}$. Crotonaldehyde (1611 $\mathrm{cm}^{-1}$ ) was detected between 473 and $673 \mathrm{~K}$. In contrast to $0.1 \% \mathrm{Rh}+2 \% \mathrm{Co} / \mathrm{CeO}_{2}$, DRIFTS showed no adsorbed acetaldehyde. It is remarkable that on $0.1 \% \mathrm{Rh} / \mathrm{CeO}_{2}$, no linearly adsorbed CO was found, but only a weak band at 1980 $\mathrm{cm}^{-1}$, attributable to bridge-bonded CO.

From our observations, we conclude that the promoter $\mathrm{Rh}$ has at least two different roles in this catalytic system. First, the reduction of $\mathrm{Co}$ (and $\mathrm{CeO}_{2}$ ) in $\mathrm{H}_{2}$ was much more efficient in the presence of $\mathrm{Rh}$ (Figures 1 and 2). Because $\mathrm{H}_{2}$ is also present as a product, $\mathrm{Rh}$ may also help to keep the cobalt in the metallic state. On the other hand, $\mathrm{Rh}$ promotes the $\mathrm{C}-\mathrm{C}$ bond scission reaction of ethanol, producing adsorbed $\mathrm{CH}_{3}{ }^{7,79}$ This is in agreement with the fact that on our $\mathrm{Rh}$-containing samples, the selectivities for methane are higher than for the $\mathrm{CeO}_{2}$ and $\mathrm{Co} / \mathrm{CeO}_{2}$ systems. The reaction of ethanol on metallic cobalt was investigated earlier on a Co foil. ${ }^{41}$ In this study, the primary reaction of ethoxide species on the metallic cobalt surface was decarbonylation, presumably through acetaldehyde and acetyl species, producing $\mathrm{H}_{2}, \mathrm{CO}$, and carbon. Taking into account these observations, we propose that Reactions 9 and 10 are main reaction steps on $0.1 \% \mathrm{Rh}+$ $2 \% \mathrm{Co} / \mathrm{CeO}_{2}$ catalyst, followed by Reactions $14-16$ :

$$
\begin{aligned}
& \mathrm{CH}_{3(\mathrm{ads})} \rightarrow \mathrm{C}_{(\mathrm{ads})}+\mathrm{H}_{(\mathrm{ads})}+\mathrm{H}_{2(\mathrm{~g})} \\
& \mathrm{CH}_{3(\mathrm{ads})}+\mathrm{H}_{(\mathrm{ads})} \rightarrow \mathrm{CH}_{4(\mathrm{~g})} \\
& 2 \mathrm{H}_{(\mathrm{ads})} \rightarrow \mathrm{H}_{2(\mathrm{~g})}
\end{aligned}
$$

The products of these reaction steps were detected in gas phase and identified in FTIR spectra. The hydrogen selectivity significantly increased in the presence of a small amount of Rh. The fact that the bimetallic catalyst was the most active and selective for hydrogen production and at the same time it contained the largest fraction of $\mathrm{Co}$ in metallic state indicates that metallic cobalt sites are active in the SRE reaction. This conclusion is different from previous suggestions that claim that metallic cobalt sites are mainly active in the carbon formation reaction. ${ }^{39,41}$ Most likely, both $\mathrm{Co}^{2+}$ and metallic Co play roles 
in different steps of the SRE reaction. For example, $\mathrm{Co}^{2+}$ is active in the dehydrogenation of ethanol, whereas metallic sites are particularly active in $\mathrm{C}-\mathrm{C}$ bond rupture and decarbonylation.

It is worth mentioning that acetone was not detected in the gas phase on $\mathrm{Rh}$-promoted $\mathrm{Co} /$ ceria. Acetone was produced through aldol condensation of acetaldehyde; however, this type of reaction requires $\mathrm{Co}^{\mathrm{x}+}$ centers on the surface that are not found in the presence of Rh. Alternatively, in the formation of acetone on $\mathrm{CeO}_{2}$, stoichiometric $\mathrm{CeO}_{2}$ is involved, although on $\mathrm{Rh}-\mathrm{Co} / \mathrm{CeO}_{2}$, cerium ions are also greatly reduced.

The amount of acetate was less on the bimetallic catalyst, indicating that its formation from aldehyde requires more mobile lattice oxygen or $\mathrm{OH}$ groups, which are better available without rhodium. As it was shown that $\mathrm{Rh}$ catalyzes the demethanation of acetate to form carbonate species and $\mathrm{CO}_{2}$, this process might be an additional hydrogen source (Figure 8B).

\section{CONCLUSIONS}

The steam reforming of ethanol was studied under identical conditions on different oxide-supported Co-based catalysts with a Co content of $2 \%$. The catalysts were characterized by TPR and XPS, and the conversion of ethanol and the product distribution were determined by gas chromatography between 300 and $1073 \mathrm{~K}$. The transiently formed surface intermediates were identified by in situ DRIFTS. In the following the most important results and conclusions are summarized: (1) Upon TPR to $773 \mathrm{~K}$, cobalt was not reduced to $\mathrm{Co}^{0}$ on the alumina support. In contrast, on silica, the majority of cobalt was reduced to the metallic state upon TPR to $773 \mathrm{~K}$. The behavior on ceria is intermediate, with about half of the cobalt was reduced to $\mathrm{Co}^{0}$ and half remaining in the $\mathrm{Co}^{2+}$ state. When a small amount $(0.1 \%) \mathrm{Rh}$ was added to the Co/ceria system, the reducibility dramatically changed, that is, cobalt was completed reduced to the metallic $\mathrm{Co}^{0}$ state. In addition, also the ceria support was reduced significantly. The effects can be explained by hydrogen spillover phenomena. (2) On the acidic Co/ $\mathrm{Al}_{2} \mathrm{O}_{3}$ catalyst, the highest ethanol conversion was detected at lower temperature, and ethylene was the main product; the hydrogen selectivity was almost zero at $723 \mathrm{~K}$. On $\mathrm{Co} / \mathrm{SiO}_{2}$ hydrogen, acetaldehyde, $\mathrm{CO}_{2}$ and $\mathrm{CO}$ were the dominant products, but the activity was rather poor. The basic $\mathrm{Co} / \mathrm{CeO}_{2}$ catalyst displayed high activity in ethanol steam reforming; at $723 \mathrm{~K}$ hydrogen, acetone, $\mathrm{CO}_{2}$, and $\mathrm{CO}$ were the main products. In the presence of $\mathrm{Rh}$ promoter, the product distribution significantly altered, and the catalyst was more stable; the hydrogen selectivity significantly increased, and $\mathrm{CO}_{2}, \mathrm{CO}, \mathrm{CH}_{4}$, and some aldehyde were produced, but no acetone formation was detected. (3) As is generally accepted, the first step in ethanol activation is the formation of ethoxide. On $\mathrm{Co} / \mathrm{Al}_{2} \mathrm{O}_{3}$, acetate was identified as the main other adsorbed species in DRIFTS, and no adsorbed $\mathrm{CO}$ was detected. On the $\mathrm{Co} / \mathrm{CeO}_{2}$ catalyst ethoxide, adsorbed ethanol, acetate, crotonaldehyde, and carbonate were identified as significant adsorbed species, and again no adsorbed $\mathrm{CO}$ was found. When the $\mathrm{Rh}$ modifier was added to the $\mathrm{Co} / \mathrm{CeO}_{2}$, the stability of ethoxide decreased, and linearly adsorbed $\mathrm{CO}$ appeared in the IR spectra between 373 and $673 \mathrm{~K}$. The amount of acetate was lower, and in a narrow temperature range $(423-573 \mathrm{~K})$, acetaldehyde and traces of crotonaldehyde were observed. The promoting effect of $\mathrm{Rh}$ was mainly rationalized by an increased efficiency in $\mathrm{C}-$ $\mathrm{C}$ bond rupture on both $\mathrm{Rh}$ and metallic Co sites.

\section{ASSOCIATED CONTENT}

\section{S Supporting Information}

Additional conversion and selectivity data for the studied catalysts. This information is available free of charge via the Internet at http://pubs.acs.org/.

\section{AUTHOR INFORMATION}

\section{Corresponding Author}

*E-mail: jkiss@chem.u-szeged.hu.

\section{Notes}

The authors declare no competing financial interest.

\section{ACKNOWLEDGMENTS}

The financial support by the Alexander von Humboldt Foundation within the Research Group Linkage Programme, by COST Action Nanoalloy MP0903, as well as by TÁMOP4.2.2.A-11/1/KONV-2012-0047 is acknowledged. H.-P.S. and C.P. acknowledge support by the Cluster of Excellence "Engineering of Advanced Materials".

\section{REFERENCES}

(1) Brown, L. F. Int. J. Hydrogen Energy 2001, 26, 381-397.

(2) Haryanto, A.; Fernando, S.; Murali, N.; Adhikari, S. Energy Fuels 2005, 19, 2098-2106.

(3) Vaidya, P. D.; Rodrigues, A. E. Chem. Eng. J. 2006, 117, 39-49.

(4) Ni, M.; Leung, Y. C.; Leung, M. K. H. Int. J. Hydrogen Energy 2007, 32, 3238-3247.

(5) de la Piscina, P. R.; Homs, N. Chem. Soc. Rev. 2008, 37, 24592467.

(6) Mattos, L. V.; Jacobs, B. H.; Noronha, F. B. Chem. Rev. 2012, 112, 4094-4123.

(7) Yee, A.; Morrison, S. J.; Idriss, H. Catal. Today 2000, 63, 327335.

(8) Aupretre, F.; Descorme, C.; Duprez, D. Catal. Commun. 2002, 3, 263-267.

(9) Song, H.; Ozkan, U. S. J. Catal. 2009, 261, 66-74.

(10) Bayram, B.; Soykal, I. I.; Deak, D.; Miller, J. T.; Ozkan, U. S. J. Catal. 2011, 284, 77-89.

(11) Song, H.; Mirkelamoglu, B.; Ozkan, U. S. Appl. Catal., A 2010, $382,58-64$

(12) Badlani, M.; Wachs, I. E. Catal. Lett. 2001, 75, 137-149.

(13) Kulkarni, D.; Wachs, I. E. Appl. Catal., A 2002, 237, 121-137.

(14) Erdőhelyi, A.; Raskó, J.; Kecskés, T.; Tóth, M.; Dömök, M. Catal. Today 2006, 116, 367-376.

(15) Yee, A.; Morrison, S. J.; Idriss, H. J. Catal. 1999, 186, 279-295.

(16) Lin, S. S.-Y.; Kim, D. H.; Ha, S. Y. Catal. Lett. 2008, 122, 295301.

(17) Llorca, J.; Homs, N.; Sales, J.; de la Piscina, P. R. J. Catal. 2002, 209, 306-317.

(18) Llorca, J.; Homs, N.; de la Piscina, P. R. J. Catal. 2004, 227, $556-560$.

(19) Lin, S. S.-Y.; Kim, D. H.; Ha, S. Y. Appl. Catal., A 2009, 355, 69-77.

(20) Ponec, V. Stud. Surf. Sci. Catal. 1991, 64, 117-157.

(21) Guczi, L.; Boskovic, G.; Kiss, E. Catal. Rev. 2010, 52, 133-203.

(22) Johnson, B. G.; Bartholomew, C. H.; Goodman, D. W. J. Catal. 1991, 128, 231-247.

(23) Ho, S.-W.; Houalla, M.; Hercules, D. M. J. Phys. Chem. 1990, 94, 6396-6399.

(24) Khodakov, A. Y.; Griboval-Constant, A.; Bechara, R.; Zholobenko, V. L. J. Catal. 2002, 206, 230-241.

(25) Kaspar, J.; Fornasiero, P.; Graziani, M. Catal. Today 1999, 50, 285-298.

(26) Catalysis by Ceria and Related Materials;Trovarelli, A., Ed.; Imperial College Press: London, 2002. 
(27) Happel, M.; Myslivecek, J.; Johánek, V.; Dvorak, F.; Stetsovych, O.; Lykhach, Y.; Matolín, V.; Libuda, J. J. Catal. 2012, 289, 118-126.

(28) da Silva, A. M.; de Souza, K. R.; Mattos, L. V.; Jacobs, G.; Davis,

B. H.; Noronha, F. B. Catal. Today 2011, 164, 234-239.

(29) Martono, E.; Vohs, J. V. ACS Catal. 2011, 1, 1414-1420.

(30) Mavrikakis, M.; Barteau, M. J. Mol. Catal. A 1998, 131, 135147.

(31) Diagne, C.; Idriss, H.; Kiennemann, A. Catal. Commun. 2002, 3, 565-571.

(32) Sheng, P.-Y.; Yee, A.; Bowmaker, G. A.; Idriss, H. J. Catal. 2002, 208, 393-403.

(33) Raskó, J.; Hancz, A.; Erdőhelyi, A. Appl. Catal., A 2004, 269, $13-25$.

(34) Tóth, M.; Dömök, M.; Raskó, J.; Hancz, A.; Erdőhelyi, A. Chem. Eng. Trans. 2004, 4, 229-234.

(35) Raskó, J.; Dömök, M.; Baán, K.; Erdőhelyi, A. Appl. Catal., A 2006, 299, 202-211.

(36) Raskó, J.; Kiss, J. Appl. Catal., A 2005, 287, 252-260.

(37) Weststrate, C. J.; Gericke, H. J.; Verhoeven, M. W. G. M.; Ciobica, I. M.; Saib, A. M.; Niemantsverdriet, J. W. J. Phys. Chem. Lett. 2011, 1, 1767-1770.

(38) Mullins, D. R.; Senanayake, S. D.; Chen, T.-L. J. Phys. Chem. C 2010, 114, 17112-17119.

(39) Martono, E.; Vohs, J. M. J. Catal. 2012, 291, 79-86.

(40) Martono, E.; Hyman, M. P.; Vohs, J. M. Phys. Chem. Chem. Phys.

2011, 13, 9880-9886.

(41) Hyman, M. P.; Vohs, J. M. Surf. Sci. 2011, 605, 383-389.

(42) Batista, M. S.; Santos, R. K. S.; Assaf, E. M.; Assaf, J. M.; Ticianelli, E. A. J. Power Sources 2003, 124, 99-103.

(43) Óvári, L.; Krick Calderon, S.; Lykhach, Y.; Libuda, J.; Erdőhelyi, A.; Papp, C.; Kiss, J.; Steinrück, H.-P. J. Catal. 2013, 307, 132-139.

(44) Virgine, M.; Araque, M.; Roger, A.-C.; Vargas, J. C.; Kiennemann, A. Catal. Today 2008, 138, 21-27.

(45) Profeti, L. P. R.; Ticianelli, E. A.; Assaf, E. M. J. Power Sources 2008, 175, 482-489.

(46) Cook, K. M.; Poudyal, S.; Miller, J. T.; Bartholomew, C.; Hecker, W. C. Appl. Catal., A 2012, 449, 69-80.

(47) Jongsomjit, B.; Panpranot, J.; Goodwin, J. G. J. Catal. 2001, 204, 98-109.

(48) Jacobs, G.; Das, T. K.; Patterson, P. M.; Li, J.; Sanchez, L.; Davis, B. H. Appl. Catal., A 2003, 247, 335-343.

(49) Schanke, D.; Vada, S.; Blekkan, E. A.; Hilmen, A. M.; Hoff, A.; Holmen, A. J. Catal. 1995, 156, 85-95.

(50) Prieto, G.; Concepcion, P.; Murciano, R.; Martinez, A. J. Catal. 2013, 302, 37-48.

(51) Pereira, E. B.; Homs, N.; Marti, S.; Fierro, J. L. G.; de la Piscina, P. R. J. Catal. 2008, 257, 206-214.

(52) Prieto, G.; Martinez, A.; Concepcion, P.; Moreno-Tost, R. J. Catal. 2009, 266, 129-144.

(53) Yao, H. C.; Yu Yao, Y. T. J. Catal. 1984, 86, 254-265.

(54) Jacobs, G.; Ji, Y.; Davis, B. H.; Cronauer, D.; Kropf, A. J.; Marshall, C. L. Appl. Catal., A 2007, 333, 177-191.

(55) Noronha, F. B.; Frydman, A.; Aranda, D. A. G.; Perez, C.; Soares, R. R.; Morawek, B.; Castner, D.; Campbell, C. T.; Frety, R.; Schmal, M. Catal. Today 1996, 28, 147-157.

(56) Lin, S. S.-Y.; Kim, D. H.; Engelhard, M. H.; Ha, S. Y. J. Catal. 2010, 273, 229-235.

(57) Chin, R. L.; Hercules, D. M. J. Phys. Chem. 1982, 86, 360-367.

(58) Burroughs, P.; Hamnett, A.; Orchard, A. F.; Thornton, G. J. Chem. Soc., Dalton Trans. 1976, 17, 1686-1698.

(59) Pfau, A.; Schierbaum, K. D. Surf. Sci. 1994, 321, 71-80.

(60) Fujimori, A. Phys. Rev. B 1983, 28, 4489-4499.

(61) Mullins, D. R.; Overbury, S. H.; Huntley, D. R. Surf. Sci. 1998, 409, 307-319.

(62) Guil, J. M.; Homs, N.; Llorca, J.; de la Piscina, P. R. J. Phys. Chem. B 2005, 109, 10813.

(63) Vargas, J. C.; Libs, S.; Roger, A. C.; Kiennemann, A. Catal. Today 2005, 107, 417.
(64) Dömök, M.; Tóth, M.; Raskó, J.; Erdőhelyi, A. Appl. Catal., B 2007, 69, 262-272.

(65) Raskó, J.; Kiss, J. Catal. Lett. 2005, 101, 71-77.

(66) Óvári, L.; Solymosi, F. Langmuir 2002, 18, 8829-8835.

(67) Di Cosimo, J. I.; Diez, V. K.; Xu, M.; Iglesia, E.; Apesteguia, C. R. J. Catal. 1998, 178, 499-510.

(68) Christiansen, M. A.; Mpourmpakis, G.; Vlachos, D. G. ACS Catal. 2013, 3, 1965-1975.

(69) Li, M.; Wu, Z.; Overbury, S. H. J. Catal. 2013, 306, 164-176.

(70) Vayssilov, G. N.; Mihaylov, M.; St. Petkov, P.; Hadjiivanov, K. I.; Neyman, K. M. J. Phys. Chem. C 2011, 115, 23435-23454.

(71) Yee, A.; Morrison, S. J.; Idriss, H. J. Catal. 2000, 191, 30-45.

(72) Idriss, H.; Diagne, C.; Hinderman, J. P.; Kiennemann, A.; Barteau, M. A. J. Catal. 1995, 155, 219-237.

(73) Soykal, I. I.; Sohn, H.; Ozkan, U. S. ACS Catal. 2012, 2, 23352348.

(74) Soykal, I. I.; Bayram, B.; Sohn, H.; Gawade, P.; Miller, J. T.; Ozkan, U. S. Appl. Catal., A 2012, 449, 47-58.

(75) Singh, M.; Zhou, N.; Paul, D. K.; Klabunde, K. J. J. Catal. 2008, 260, 371-379.

(76) Solymosi, F.; Pásztor, M. J. Phys. Chem. 1985, 89, 4789-4793.

(77) Gazsi, A.; Koós, Á.; Bánsági, T.; Solymosi, F. Catal. Today 2011, $160,70-80$.

(78) da Silva, A. M.; de Souza, K. R.; Jacobs, G.; Graham, U. M.; Davis, B. H.; Mattos, L. V.; Noronha, F. B. Appl. Catal., B 2011, 102, 94-109.

(79) Zhang, J.; Zhong, Z.; Cao, X.-M.; Hu, P.; Sullivan, M. B.; Chen, L. ACS Catal. 2014, 4, 448-456. 